\title{
PENDEKATAN POSITIVISTIK DALAM STUDI HUKUM ADAT
}

\author{
Rikardo Simarmata* \\ Departemen Hukum Agraria Fakultas Hukum Universitas Gadjah Mada \\ Jalan Sosio Yustisia No.1 Bulaksumur, Sleman, D.I Yogyakarta 55281
}

\begin{abstract}
Adat Positive Legal Science was initiated to simplify Western People (officer, legal enforcer, scholar) to understand adat or adat law. There are two important process to produce and to formulate substance of Adat Positive Legal Science. First, introduction of positivism legal approach creates perspective seeing adat law as jurisprudence because it has elements supporting adat law as system. This approach differenciates Adat Positive Legal Science from adat law study based on social approach. Adat law social approach does not imagine universal elements which represent reality of adat and adat law diversity because its own uniqueness. This different dissociate Adat Positive Legal Science from social studies as initial references. Second, introduction of positivism approach is action to apply western legal thoughts to explain adat law. The result is bias explanation regarding adat law. It is argued that positivism approach in Adat Positive Legal Science sets apart nature of adat law which following dynamics social relation. This paper doesn not only elaborate the birth of Adat Positive Legal Science history, but also how Adat Positive Legal Science does not able to response dynamic adat law by looking back to the existing concepts and definitions.
\end{abstract}

Keywords: adat law study, legal posivism, adat law.

\section{Intisari}

Ilmu Hukum Adat Positifpada awalnya digagas untuk keperluan memudahkan Orang Barat (pejabat, penegak hukum, ilmuwan) untuk memahami adat atau hukum adat. Ada dua hal penting dari proses melahirkan dan merumuskan muatan Ilmu Hukum Adat Positif ini. Pertama, introduksi pendekatan positivisme menghasilkan pandangan yang melihat hukum adat sebagai jurisprudence dan karena itu memiliki unsurunsur yang menjadi penopang hukum adat sebagai sistem. Pendekatan ini mengakibatkan Ilmu Hukum Adat Positif menjadi berbeda dari studi-studi hukum adat yang menggunakan pendekatan sosial. Kajian sosial hukum adat tidak membayangkan ada unsur-unsur universal yang bisa merepresentasikan adat atau hukum adat, yang dalam kenyataanya beragam karena memiliki keunikan-keunikan. Perbedaan ini sekaligus menjauhkan Ilmu Hukum Adat Positif dari studi-studi sosial, yang dijadikannya sebagai rujukan awal. Kedua, introduksi pendekatan positivisme sekaligus merupakan tindakan menerapkan pemikiranpemikiran Hukum Barat (western legal thoughts) dalam menggambarkan hukum adat. Hasilnya, sebagian gambaran mengenai hukum adat yang dihasilkan dari pendekatan ini, bersifat bias. Tulisan ini berargumen bahwa pendekatan posivistik dalam Ilmu Hukum Adat Positif telah membuat disiplin ini menjauh dari sifat alamiah hukum adat yaitu yang terus berkembang mengikuti proses dinamik relasi-relasi sosial. Tulisan ini, selain memaparkan sejarah kelahiran Ilmu Hukum Adat Positif, juga memperlihatkan bagaimana Ilmu Hukum Adat Positif tidak mampu merespon dinamika pada hukum adat dengan cara melihat ulang istilah dan konsep-konsep yang digunakan beserta pengertiannya.

Kata Kunci: kajian hukum adat, positivisme hukum, hukum adat.

\section{Pokok Muatan}

A. Pendahuluan 466

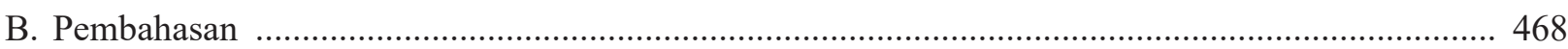

1. Perkembangan Studi Hukum Adat Positivistik........................................................................... 468

2. Pandangan Dasar Ilmu Hukum Adat Positif ....................................................................................... 474

3. Mempersoalkan Dalil-Dalil Ilmu Hukum Adat Positif................................................................. 478

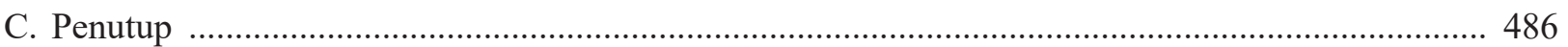

\footnotetext{
Alamat korespondensi: rikardosim@gmail.com.
} 


\section{A. Pendahuluan}

Pendekatan ilmiah dalam studi hukum adat diawali oleh pendokumentasian adat-adat sejumlah daerah di wilayah Nusantara, oleh sederetan penyiar agama, pejabat pemerintahan kolonial Belanda, dan ilmuwan. Dokumentasi adat tersebut berisi lukisan mengenai pandangan hidup, nilai dan praktik-praktik kehidupan yang disenggarakan oleh penduduk Golongan Pribumi. Dokumentasi sebagian besar bersumber dari kitab-kitab (codes) yang diinisiasi oleh kerajaan-kerajaan di Nusantara, dan sebagian kecil berasal dari penyelidikan lapangan. Periode emas kegiatan pendokumentasian berlangsung pada paruh kedua abad ke-19. Sebagian hasil dokumentasi dipublikasikan dalam jurnal-jurnal ilmiah di Negeri Belanda. Tidak heran, karena kehadiran dan dokumentasi dan publikasi tersebut, John Ball menamai periode ini sebagai permulaan dari kajian ilmiah mengenai adat. ${ }^{1}$

Kehadiran dokumentasi bahan-bahan adat tersebut membuat pengetahuan mengenai adat atau hukum adat tidak lagi milik eksklusif para pengurus adat. Pengetahuan berbasis ilmiah dan tradisi tersebut hidup bersamaan. Pengetahuan para pengurus adat mengenai hukum adat tidak diukur dari tulisan-tulisan yang mereka hasilkan tetapi dari hal yang konkret yaitu pengalaman dan kemampuan menyelesaikan perkara-perkara adat.

Pendekatan ilmiah dalam studi hukum adat berkembang terus sebagai dampak dari perjuangan membela keberlakuan hukum adat dan pada saat yang sama menolak pemberlakuan Hukum Barat kepada Golongan Pribumi di Hindia Belanda. Pembelaan dilakukan sebagai bagian dari menjalankan semangat Politik Etis yang kala itu ditopang kuat oleh paham humanisme. ${ }^{2}$ Tujuan lebih konkret dari perjuangan ini adalah mendorong terbentuknya tata kelola pemerintahan yang baik, khususnya dalam bidang peradilan, di Hindia Belanda. ${ }^{3}$

Perjuangan di ranah politik tersebut menstimulasi perkembangan pada arena akademik yaitu keinginan untuk menjadikan studi hukum adat positif sebagai disiplin mandiri dalam ilmu hukum positif yang sejajar dengan misalnya ilmu hukum perdata. Bersamaan dengan keinginan itu adalah kemauan untuk menjauhkan diri dari pengaruh ilmu-ilmu sosial. Hasil akhir yang diperjuangkan oleh gagasan ini adalah melahirkan ilmu hukum adat yang menunjukan karakter sebagai sebuah jurisprudence. ${ }^{4}$

Keinginan untuk memandirikan Ilmu Hukum Adat Positif tidak lepas dari kebutuhan para ilmuwan dan penyelenggara negara kolonial, yang terbiasa dengan tradisi pemikiran Hukum Barat, untuk dapat memahami dan menggunakan hukum adat dengan tepat dan efektif. Pendekatan positivisme dianggap memudahkan para ilmuwan dan penyelenggara negara untuk memahami hukum adat termasuk caranya berfungsi. Bagi ilmuwan Barat yang membela hukum adat, pendekatan ini membantu mereka menjelaskan hukum adat kepada pejabat kolonial secara rasional. Bagi penyelenggara negara kolonial, pendekatan ini memungkinkan mereka mengintegrasikan hukum adat kedalam sistem peradilan (criminal justice system) sehingga dapat berfungsi untuk menyelesaikan perkaraperkara adat. Intinya, pendekatan positivistik telah menjadi bahasa bersama yang memungkinkan para ilmuwan dan penyelenggara negara kolonial berkomunikasi mengenai hukum adat.

Studi hukum adat positivistik bisa dikatakan merupakan sinonim bagi tiga pendekatan lainnya yaitu: formalisme hukum; pandangan yang melihat hukum adat sebagai jurisprudence; dan pendekatan doktrinal terhadap hukum. Ketiga istilah ini menunjuk pada hal yang sama yaitu suatu pemikiran

John Ball, 1982, Indonesian Legal History 1602-1848, Oughtershaw Press, Sydney, hlm. 195.

Robert Cribb, "Legal Pluralism and Criminal Law in the Dutch Colonial Order", Indonesia, No. 90, Oktober 2010 , hlm. 49.

H.W.J. Sonius, "Introduction", dalam J.F. Holleman, 1981, Van Vollenhoven on Indonesian Adat Law. Martinus Nijhoff, The Hague, hlm. XXXVI.

Istilah 'jurisprudence' dalam hal ini dipahami sebagai suatu perspektif yang mendekati hukum sebagai suatu sistem dengan elemen-elemen yang tersusun secara hirarkis. Elemen-elemen tersebut adalah prinsip-prinsip umum (konsep, asas) dan norma-norma. Lihat dalam Hugh Collins, 2001, Marxism and Law, Oxford University Press, Ney York. 
yang berpegang pada keyakinan bahwa, Pertama, hukum adat merupakan sebuah sistem yang tersusun atas sejumlah unsur atau kategori. Cara berbagai unsur atau kategori tersebut melangsungkan relasi tunduk pada kaidah-kaidah hirarkisme sehingga membentuk pola. Relasi berlangsung secara deterministik dalam pengertian pembuatan atau penggunaan suatu unsur dilakukan dengan merujuk pada unsur lain yang berkedudukan lebih tinggi dalam hirarki. Bagi pandangan yang menganggap hukum adat sebagai jurisprudence, unsur yang menempati kedudukan paling tinggi adalah asas. Unsur ini berciri abstrak dan karena itu dapat berlaku pada berbagai tempat dan waktu. Sejajar dengan unsur ini adalah doktrin. Dibawah asas atau doktrin terdapat norma dengan sifat konkret dan karena itu hanya dapat berlaku pada tempat dan waktu tertentu.

Kedua, pengoperasian sistem, yang meliputi pembuatan dan pelaksanaan, dipercayakan kepada kelompok tertentu yang dianggap memiliki kompetensi. Ukuran kompetensi adalah pengetahuan yang memadai mengenai: (i) unsurunsur pembentuk sistem; dan (ii) nalar berpikir mengenai bagaimana antar unsur berhubungan, dan bagaimana kasus atau perselisihan diselesaikan. Pihak-pihak yang terlibat dan nalar pikir yang digunakan dalam proses pengoperasian menentukan legitimasi atas produk yang dihasilkan.

Studi hukum adat yang didekati dengan jurisprudence telah menjadi paket kurikulum pada pendidikan hukum di Hindia Belanda sejak awal abad keduapuluh ketika Sekolah Hukum (Rechtsschool) didirikan pada tahun 1909, disusul dengan Sekolah Tinggi Hukum (Rechtshogeschool), Batavia, di tahun 1924..$^{5}$ Di Negeri Belanda, kurikulum demikian mulai diberikan sejak tahun 1921 pada saat Universitas Leiden membuka Fakultas Ilmu Hukum dan Sastra yang menawarkan program master untuk tiga kejuruan yaitu Hukum di Hindia Belanda, Bahasa-Bahasa Timur, dan Indologi. ${ }^{6}$

Ketiga lembaga pendidikan hukum tersebut sama-sama mengajarkan para mahasiswanya mata kuliah mengenai hukum adat dengan konsentrasi hukum keluarga, pewarisan, dan tanah. ${ }^{7}$ Pada mata kuliah ini, para mahasiswa mendapatkan pengajaran mengenai konsep, nilai, dan norma-norma hukum adat yang telah dipilah-pilah berdasarkan kategorisasi. Misalnya kategori hukum keluarga, dan hukum tanah. Selain itu, mahasiswa dijelaskan mengenai penyelesaian-penyelesaian perselisihan atau pelanggaran hukum adat oleh pengurus adat yang sekaligus menunjukan bentuk nalar berpikir yang digunakan.

Menariknya, sekalipun sudah berusia lebih dari 100 tahun, paket kurikulum ini masih belum mengalami perubahan mendasar sampai saat ini. Hampir tidak ada perubahan pada cakupan objek atau lapangan kurikulum pengajaran setelah diajarkan lebih dari satu dekade. Satu cara mudah untuk memperlihatkan absennya perubahan tersebut adalah dengan melihat buku-buku teks hukum adat. Dari buku yang ditulis oleh Barend J. Ter Haar berjudul 'Beginselen en stelsel van het adatrecht' yang terbit pada tahun 1939, buku tulisan Roelof van Dijk berjudul 'Pengantar Hukum Adat Indonesia' (edisi terjemahan), terbitan tahun 1954, buku tulisan R. Soepomo berjudul 'Bab-bab tentang Hukum Adat, terbitan tahun 1962, sampai terbitan terkini, masih dengan susunan pokok bahasan yang

Rechtsschool dan Rechtshogeschool merupakan sekolah untuk anak-anak Golongan Pribumi, ditujukan untuk menghasilkan lulusan yang memiliki keahlian hukum guna menjadi aparatur pada institusi peradilan (rechtsambtenaren). Lihat dalam Soetandyo Wignjosoebroto, 1994, Dari Hukum Kolonila ke Hukum Nasional: suatu kajian tentang dinamika sosial-politik dalam perkembangan hukum selama satu setengah abad di Indonesia, 1840-1990, Rajagrafindo Persada, Jakarta, hlm. 147-8, dan 161. Rechtsschool, yang merupakan sekolah tingkat menengah, menerima anak usia dua belas sampai tigas belas tahun. Sedangkan Rechtshogeschool menerima usia tujuh belas sampai delapan belas tahun. Masa studi Rechtsschool adalah enam tahun, sedangkan Rechtshogeschool selama 3 tahun, Lihat Upik Djalins, "Re-examining subjek making in the Netherlands East Indies Legal Education: pedagogy, curriculum, and colonial state formation", Itinerario, Vol. XXXVII, No. 2, 2013, hlm. 123-24, dan 135. Menyusul pendirian Rechtshogeschool, pemerintah kolonial menutup Rechtsschool pada tahun 1928, Lihat Soetandyo Wignjosoebroto, Ibid., hlm. 153.

Upik Djalins, "Re-examining subjek making in the Netherlands East Indies Legal Education: pedagogy, curriculum, and colonial state formation", Itinerario, Vol. XXXVII, No. 2, 2013, hlm. 129.

Ibid., hlm. 126. 
sama, yaitu susunan masyarakat, dan pembidangan dalam hukum adat.

Fakta bahwa tidak terjadi perubahan berarti pada materi pengajaran hukum adat dalam kurun waktu yang sangat lama mengindikasikan adanya sifat statik pada Ilmu Hukum Adat Positif. Ini memunculkan tanda tanya karena pada saat yang sama selama kurun waktu tersebut (hukum) adat dalam kenyataanya terus berkembang sesuai sifat alamiahnya yang dinamis. Pertanyaan utamanya adalah mengapa bisa tidak terjadi perubahan pada suatu cara atau alat, dalam hal ini Ilmu Hukum Adat Positif, sementara objek yang dijelaskannya berubah secara terus-menerus? Pertanyaan ini menyulut lahirnya tanda tanya lainnya yaitu bagaimana sebenarnya aspek epistemologi dari pendekatan ini dalam memahami hukum adat, yang menentukan akurasinya dalam menjelaskan kenyataan?

Tulisan ini menelusuri seluk beluk Ilmu Hukum Adat Positif dengan mencermati tiga hal pada pendekatan ini. Pertama, proses kelahiran, tujuan serta penjelasan-penjelasan mengapa pendekatan ini diperlukan. Kedua, dalil-dalil utama yang menopang pendekatan ini termasuk konstruksinya mengenai pengertian hukum adat. Selain menjelaskan kedua hal tersebut, yang Ketiga, tulisan ini juga mengemukakan kritik atas rumusanrumusan Ilmu Hukum Adat Positif mengenai pengertian hukum adat, dan caranya menjelaskan perkembangan hukum adat.

\section{B. Pembahasan}

\section{Perkembangan Studi Hukum Adat Positivistik}

Seperti sudah disebutkan, pendekatan ilmiah terhadap hukum adat dimulai dengan kegiatan pendokumentasian, dalam bentuk kompilasi, hukum-hukum adat yang masa keemasaanya berlangsung dari akhir paruh pertama abad ke19 sampai awal abad ke-20. Adalah Cornelis Van Vollenhoven (1874-1933) yang dianggap berhasil membuat kompilasi yang oleh Sonius dinilai terstruktur, padu, dan self-generating whole. ${ }^{8}$ Kompilasi tersebut dituangkan kedalam buku berjudul Het Adatrecht van Netherlandsche, yang terdiri dari 3 jilid. ${ }^{9}$ Namun, berhubung baru dibuat pada awal abad ke-20 sementara kegiatan serupa sudah dimulai sekitar 60 tahun sebelumnya, kompilasi ini berhutang banyak pada bahanbahan etnografi hukum yang disiapkan oleh para pendahulu Van Vollenhoven. Para pendahulunya memiliki latar belakang sebagai pejabat pemerintah kolonial, penyiar agama, akademisi, dan professional. ${ }^{10}$ Pejabat pemerintahan diantaranya Marsden, Muntinghe, Thomas Stanford Raflles, John Crawfurd, Jean Chretien Baud, F.A. Liefrinck, Nederburgh, dan Ossenbruggen, ${ }^{11}$ penyiar agama N. Graafland, C. Poensen, dan R. van Eck, akademisi Wilken, dan Snocuk Hurgronje, dan professional J.H. Carpentier Alting.

Van Vollenhoven memberi pujian kepada beberapa nama karena kualitas kompilasi dan pendekatan yang digunakan. Untuk karya Marsden dan Thomas Stamford Raffles, ia memujinya karena yang pertama menggunakan kesadaran akan adanya kesatuan dan hubungan tali-temali antar golongan suku bangsa yang memungkinkan Indonesia dapat dilihat sebagai suatu keseluruhan yang bulat. ${ }^{12}$ Selain dari laporan etnografi hukum, Van Vollenhoven juga mengandalkan artikel-artikel dalam majalah yang terbit di negeri Belanda, yang membahas hukum adat. Muhammad mengatakan

H.W.J. Sonius, Op.cit., hlm. XXXII.

Jilid Pertama berisi hukum-hukum adat di 19 wilayah adat di Hindia Belanda. Jilid Kedua berisi hukum-hukum adat Golongan Timur Jauh seperti Orang Tionghoa, Arab dan India. Jilid Ketiga, yang diterbitkan pada tahun 1933 setelah Van Vollenhoven wafat, berisi kumpulan tulisan Van Vollenhoven yang belum pernah dipublikasikan sebelumnya, Lihat T.M.C. Asser Instituut, 1992, Cornelis van Vollenhoven 18741933, The Hague, hlm. 13.

10 Selain karena alasan diatas, tindakan Van Vollenhoven mengandalkan laporan-laporan etnografi hukum sebelumnya disebabkan juga oleh faktor bahwa ia tidak pernah tinggal lama di Hindia Belanda selain 2 kali kunjungan pendek masing-masing pada tahun 1907 dan 1932.

11 Selain nama-nama diatas, Van Vollenhoven tidak lupa menyebutkan jasa para pengumpul data lapangan (field worker) yang bekerja mayoritas sebagai pamong praja dan anggota militer Belanda. Lihat Busar Muhammad, 1981, Asas-asas hukum adat (suatu pengantar), Pradnya Paramita, Jakarta, hlm. 74-75. Lihat juga H.W.J. Sonius, "Introduction", dalam J.F. Holleman, 1981, Van Vollenhoven on Indonesian Adat Law, Martinus Nijhoff, The Hague, dan John Ball, 1982, Indonesian Legal History 1602-1848, Oughtershaw Press, Sydney.

12 Busar Muhammad, Ibid., hlm. 66. 
bahwa artikel-artikel yang mulai marak sejak pertengahan abad ke-19 tersebut turut menyumbang bagi kelahiran ilmu hukum adat. ${ }^{13}$

Seperti sudah disinggung sebelumnya bahwa kebutuhan menyelenggarakan colonial administration of justice, merupakan salah satu motif dibalik penyusunan etnografi hukum. Kegiatan ini sudah dimulai sejak Hindia Belanda berada dibawah administrasi VOC (1602-1799). Tanpa didukung oleh suatu program resmi pemerintah, beberapa pejabat yang ditempatkan di sejumlah daerah, misionaris gereja, dan pedagang, berinisiatif mengumpulkan informasi-informasi mengenai adat yang berlaku pada sejumlah komunitas yang berada di wilayah kerjanya. Aspek yang dicakup oleh informasi tersebut hampir mengenai semua dimensi kehidupan seperti pemerintahan, kekerabatan, perkawinan, pewarisan, kematian, tanah, dan harta kekayaan. Informasi-informasi tersebut berikutnya dituliskan secara deskriptif.

Semenjak permulaan periode VOC sampai abad ke-19, kompilasi mengandalkan dokumentasi hukum adat yang dilakukan oleh kerajaan, dan oleh para pedagang. Kompilasi yang mengandalkan data lapangan baru berkembang pesat sejak awal abad ke-20 bersamaan dengan terus bertumbuhnya rasa ingin tahu mengenai hukum adat untuk keperluan pembentukan hukum dan pengembangan ilmu hukum adat. Kompilasi seperti ini sebelumnya sudah dilakukan dengan mengandalkan laporanlaporan pejabat kolonial kepada atasannya di Hindia Belanda atau di negeri Belanda.

Sebagai sebuah model pendokumentasian hukum adat yang dikenal sebagai restatement, kompilasi dianggap berbahaya karena berbagai alasan. Salah satu alasannya karena metode ini dinilai melahirkan hukum adat yang tidak sesuai dengan kenyataanya. Kritik ini tidak terlepas dari karakter restatement yang mendokumentasikan hukum adat dengan cara menuliskan ulang dalam bentuk yang berbeda dari penuturan aslinya. Perbedaan muncul karena pendokumentasian dilakukan dengan menerapkan kerangka berpikir hukum Barat/Negara. ${ }^{14}$ Lewat restatement hukum adat memang tampil dalam susunan yang logis dan komprehensif. ${ }^{15}$ Kritik juga ditujukan pada praktik penggunaan kompilasi yang memperlakukannya sebagai kodifikasi dan karena itu mengikat. Padahal, restatement hanya menghasilkan dokumentasi hukum adat yang tidak mengikat.

Kompilasi hukum adat oleh Van Vollenhoven masih bisa dikategorikan sebagai etnografi hukum. Namun, berhubung kompilasi yang dilakukannya tergolong sebagai restatement dengan menyajikan tampilan hukum adat seturut kerangka pikir tertentu, dalam hal ini adalah kerangka pikir hukum Barat/ Negara, maka karyanya lebih dari sekedar etnografi hukum. Dengan cara ini Van Vollenhoven sudah memperkenalkan ontologi tertentu mengenai hukum adat. Koesno mencontohkan adopsi kerangka pikir hukum Barat mengenai sanksi dalam pemikiran Van Vollenhoven. ${ }^{16}$ Konsep sanksi sebagai hukuman untuk pelanggaran atas aturan, yang sekaligus membatasi kebebasan individual, merupakan pemikiran hukum Barat. Hukum adat tidak mengenal istilah penghukuman atas pelanggaran melainkan upaya untuk menghadirkan keseimbangan sehingga tertib kosmis dapat dikembalikan.

Gelar Penemu Hukum Adat dan Bapak Hukum Adat yang diberikan kepada Van Vollenhoven oleh para ahli hukum adat generasi berikutnya, tidak karena kompilasi yang dibuatnya karena dalam batas-batas tertentu sudah dilakukan sebelumnya oleh para pendahulu. Sebenarnya Van

13 Ibid., hlm. 75.

14 Andre J. Hoekema, “A new beginning of law among indigenous peoples. Observation by legal anthropologist”, dalam F.J.M., Feldbrugge, 2003, The law's begginings, Brill Academic Publishers, The Netherlands, hlm. 186.

15 Restatement memiliki persamaan dan perbedaan dengan metode kodifikasi. Keduanya sama karena menuliskan hukum adat dalam susunan yang logis dan komprehensif. Keduanya berbeda karena: (i) kodifikasi mencakup semua tema dalam hukum adat sedangkan restatement hanya untuk tema tertentu; dan (ii) kodifikasi memiliki kekuatan mengikat, sedangkan restatement tidak mengikat, Ubink, Janine, et al., (eds.), 2011, Customary Justice: Perspective on Legal Empowerment, International Development Law Organization, Italy.

16 Mohammad Koesnoe, 1979, Catatan-catatan terhadap Hukum Adat dewasa ini, Airlangga University Press, Surabaya, hlm. 5. 
Vollenhoven sendiri yang menggunakan istilah penemu (ontdekkers) hukum adat untuk menyebut para ilmuwan Barat, khususnya orang Belanda, yang berhasil menuliskan hukum-hukum adat pada sejumlah tempat di wilayah Hindia Belanda. Tulisan-tulisan tersebut telah berfungsi sebagai penyampai berita bahwa terdapat sistem keteraturan diluar sistem formal, yang berkembang dikalangan golongan Pribumi. ${ }^{17}$ Sistem keteraturan tersebut berbasis adat. Sekalipun disebutkan sebagai penemu hukum adat, para ilmuwan Barat tersebut tidak dipahami sebagai pencipta hukum adat. Mereka hanya memperlihatkan sesuatu (adat) yang sudah ada karena sebagai the living law, hukum adat bukan dibuat tapi ditemukan dalam masyarakat.

Dengan begitu, gelar Penemu Hukum Adat seyogyanya milik banyak ilmuwan, termasuk Van Vollenhoven. Namun, pemberian gelar tersebut bersama dengan gelar Bapak Hukum Adat tidak lepas dari capaian lebih Van Vollenhoven dalam studi hukum adat yaitu menginisiasi penggunaan pendekatan positivistik dalam studi hukum adat yaitu dengan mensistematisasi hukum adat kedalam sejumlah kategori.

Sekalipun pendekatan ilmiah dalam studi hukum telah digunakan jauh sebelumnya, pendekatan positivistik baru diperkenalkan oleh Barend Ter Haar Bzn (1892-1941), mantan murid Van Vollenhoven di Universitas Leiden, sekaligus mantan kepala Rechtshogeschool, sekitar tujuh dekade sesudahnya. Salah satu bukti bahwa beliau bermaksud membawa pendekatan positivistik dalam studi ini adalah pernyataan yang disampaikannya pada peringatan ulang tahun ke-13 Sekolah Tinggi Hukum Batavia, tahun 1937. Pada kesempatan tersebut Ter Haar melontarkan pernyataan berikut ini:

[...] the science of adat private law, like any other positivistic jurisprudence, was a science of contemporary positive law, and not to be classified under legal ethnology, sociology, or historical or comparative jurisfprudence $[\ldots] .{ }^{18}$

Sebagai bagian dari membayangkan Ilmu Hukum Adat Positif, Ter Haar menemukan istilah 'sistem adat' (the system of adat). Ter Haar tidak memaksudkan istilah itu untuk menganggap adat atau hukum adat bersifat logis tetapi adanya konsistensi pada berbagai praktik adat. ${ }^{19}$

Menurut Slaats, pernyataan diatas mengindikasikan secara kuat keinginan Ter Haar untuk memasukan studi hukum adat menjadi bagian dari objek pendekatan doktrinal terhadap hukum. ${ }^{20}$ Senada dengan itu, Soekanto dalam Muhammad menyebut Ter Haar memiliki kemauan yang istimewa untuk menempatkan hukum adat sederajat dengan ilmu-ilmu hukum positif yang lain. ${ }^{21}$ Perlu diberi catatan bahwa dengan pernyataan diatas tidak berarti Ter Haar mengabaikan adanya kegunaan etnologi bagi studi hukum adat positivistik. Menurutnya, etnologi diperlukan agar ilmu hukum adat positivistik tidak keliru memahami beberapa hal dari hukum adat. ${ }^{22}$

Kendati argumen lebih lanjut dibalik keinginan tersebut tidak dapat ditelusuri dengan tuntas, setidaknya keinginan mensejajarkan hukum adat dengan ilmu hukum positif yang lain telah menunjukkan adanya upaya lain yang ingin melihat hukum adat sebagai sebuah sistem. Bagi para ahli yang membela hukum adat, cara pandang seperti ini diperlukan untuk memungkinkan mereka menyediakan pengetahuan mengenai adat atau hukum adat yang dapat diandalkan sehingga dapat dipahami oleh cara berpikir pejabat dan hakimhakim kolonial. Harapannya akhirnya adalah penyelenggaraan adminsitarsi hukum kolonial yang

\footnotetext{
Lihat Van Vollenhoven, C, 1987, Penemuan Hukum Adat, Penerbit Djambatan, Jakarta dan lihat juga Muhammad Busar, Op.cit., hlm. 57-58. H.W.J. Sonius, Loc.cit.

Andre J. Hoekema, 2003, Op.cit., hlm. 195.

Herman Slaats, et al., (ed.), 1993, Tiga Model Pendekatan Studi Hukum Adat: Suatu Laporan Penataran, Syahkuala University Press dan Pusat Studi Hukum Adat dan Islam Fakultas Hukum Universitas Syiah Kuala, Aceh, hlm. 14.

Muhammad Busar, Op.cit., hlm. 101.

Ibid., hlm. 105.
} 
menghormati keberadaan adat atau hukum adat. ${ }^{23}$

Pada aras praksis, pandangan ini dibutuhkan oleh para penegak hukum untuk menyelenggarakan sistem peradilan di negara koloni (colonial administrative of justice) yang menangani kasuskasus yang melibatkan Golongan Pribumi. Slaats mengamati hal ini dengan baik lewat kutipan berikut ini:

[...] tujuannya adalah untuk memberi bahan dasar yang lebih baik kepada para hakim dan para pejabat pemerintah yang dibebani dengan peradilan dalam mengambil keputusan $[\ldots] .{ }^{24}$

Bahan dasar yang dimaksud adalah aturanaturan adat yang dituliskan dalam bentuk kompilasi dan menjadi sumber bagi pejabat pemerintah dan hakim-hakim kolonial untuk mengetahui hukumhukum adat.

Untuk keperluan pemerintahan kolonial, dokumentasi hukum adat dalam bentuk kompilasi dimaksudkan untuk menyediakan pedoman bagi para pejabat dan hakim untuk menyelesaikan kasuskasus adat sehingga tidak menerapkan hukum adat yang berbeda pada kasus yang serupa. ${ }^{25}$ Dalam praktiknya, baik para penegak hukum maupun pembuat dan pelaksana aturan pada masa itu telah menjadikan kompilasi sebagai sumber pengetahuan mengenai hukum adat. Pada pengadilan Landraad, pengadilan Negara tingkat pertama yang menangani kasus-kasus pidana dan perdata yang melibatkan Golongan Pribumi, bersama dengan keterangan dari penghulu selaku pengurus adat yang diberikan di persidangan, dokumentasi-dokumentasi tersebut digunakan oleh para hakim sebagai rujukan untuk mengambil putusan terhadap kasus-kasus adat yang ditangani. ${ }^{26}$

Ajal menjemput Ter Haar sebelum waktunya.

Beliau meninggal dunia dalam camp tahanan militer Nazi. Pada saat meninggal, Ter Haar belum sempat menghasilkan tulisan yang menjelaskan hal ihwal pendekatan positivistik dalam studi hukum adat. Setelah kepergiannya studi hukum adat positivistik diteruskan oleh para ilmuwan Belanda dan Indonesia terutama yang pernah mengecap perkuliahan Van Vollenhoven di Universitas Leiden, dan Ter Haar di Rechtshogeschool. Pada periode setelah itu, aktivitas dominan yang terkait dengan kajian hukum adat adalah pengajaran di kampuskampus. Menariknya, materi kuliah yang diajarkan untuk hukum adat, relatif sama dari yang diajarkan di Rechtsshool dan Rechthogeschool. ${ }^{27}$

Setelah vakum selama lebih dua puluh tahun $^{28}$, kajian hukum adat lewat kegiatan penelitian menggeliat sejak dekade 70 -an. Salah satu yang berkontribusi penting adalah riset kolaboratif yang dikerjakan oleh sejumlah ilmuwan Belanda dan Indonesia pada dekade 70-an dibawah nama Bali-Lombok Project. ${ }^{29}$ Di Indonesia, kegiatan riset dilakukan secara sporadik dan tidak dibawah naungan suatu proyek riset berdurasi tahunan. Laporan-laporan riset itu menggambarkan hukumhukum adat yang berlaku disuatu tempat dan membahasnya dari sudut pandang konsep dan asas-asas hukum adat tertentu. Para peneliti yang menyiapkan laporan riset sudah berasumsi bahwa formulasi ilmu hukum adat positivistik sudah jadi

\footnotetext{
Andre J. Hoekema, Loc.cit.

Herman Slaats, et al., (Ed)., Op.cit., hlm. 14.

John Ball, Op.cit., hlm. 73.

Ibid., hlm. 187.

Herman Slaats, et al., (Ed)., Op.cit., 16-17).

Situasi vakum tersebut ditengarai disebabkan oleh perhatian para sarjana hukum yang terkuras untuk memikirkan masalah-masalah penting dalam tugas pembangunan, termasuk melaksanakan agenda revolusi (Muhammad Busar., Op.cit., hlm. 117).

29 Proyek riset ini mengiringi lahirnya lembaga riset baru bernama Institute for Folk Law, di Universitas Katolik Nijmegen, Belanda. Riset ini memiliki dua tujuan, yaitu menyelidiki hukum adat masyarakat Bali dan Lombok yang hasilnya dapat digunakan oleh hakim-hakim pengadilan dan pembentukan legislasi, dan mengembangkan riset multidisipliner pada skala internasional. Riset antroplogi hukum ini beranggotakan tim dengan latar belakang sarjana hukum dan antropolog. Selain Bali-Lombok Project, ada dua riset serupa lainnya, pada waktu yang hampir bersamaan yaitu yang dilakukan Van den Steenhoven, Herman Slaats dan K. Portier di masyarakat Karo (Sumatera Utara), dan oleh Franz Benda-Beckmann dan Keebet Benda-Beckmann di masyarakat Minangkabu (Sumatera Barat) dan Ambon. Uraian lebih lengkapnya dapat dibaca pada John Griffiths, "Recent Anthropology of Law in The Netherlands and its Historical Background", dalam Keebet von Benda-Beckmann dan Frons Strijbosch (eds.), 1986, Anthropology on law in the Netherlands: Essays in Legal Pluralism, DordrechtHolland/Cinnaminson, USA, hlm. 29-34.
} 
dan karena itu tinggal diterapkan, termasuk dalam kegiatan penelitian.

Dominannya kegiatan pengajaran dan riset penerapan konsep atau asas hukum adat, menyebabkan penjelasan awal Ter Haar mengenai ilmu hukum adat positif, relatif tidak berkembang sesudahnya. Hanya segelintir ahli hukum adat yang menulis untuk membahas formulasi pendekatan ini. Mohammad Koesnoe adalah yang paling produktif diantara sedikit orang. ${ }^{30}$

Salah satu pemikiran Koesnoe adalah pembagian studi hukum adat menjadi 3 yaitu Ilmu Adat, Ilmu Pengetahuan Hukum Adat Modern, dan Ilmu Hukum Adat Nasional. Ilmu Adat adalah pengetahuan yang dipunyai dan diterapkan oleh para petugas adat seperti cerdik pandai, pujangga dan tua-tua/pemuka adat. Dengan pengetahuan beserta kewibawaan yang dipunyai, para pengurus adat adat memastikan terselenggaranya hubungan-hubungan sosial yang berperikehidupanbermasyarakat sebagai bagian dari usaha menjamin selamatnya nilai-nilai yang dihayati dan dijunjung tinggi oleh masyarakat. Di tangan para pengurus adat, Ilmu Adat adalah seni mewujudkan nilai-nilai adat dalam kasus-kasus konkret. Hukum adat bisa didapati pada sumber-sumber lisan seperti cerita berkias, nasehat, petatah, petitih, dan gurindam yang dari sini petugas adat bisa menemukan asasasas umum. Koesnoe membagi perkembangan Ilmu Adat kedalam empat tahapan yaitu: (i) hidup dan berkembang dalam lingkungan masyarakat lokal; (ii) hidup dan berkembang dalam lingkungan kerajaan; (iii) hidup dan berkembang pada masa kolonialisme (1400-1945); dan (iv) hidup dan berkembang dalam masa kemerdekaan (1945-sekarang). ${ }^{31}$

Ilmu Pengetahuan Hukum Adat Modern lahir dan berkembang dimasa pemerintahan kolonial Belanda. Etnografi hukum adat dan sistematisasi terhadapnya dalam bentuk kompilasi dianggap sebagai wujud dari Ilmu Pengetahuan Hukum Adat Modern. Koesnoe membagi Ilmu Pengetahuan Hukum Adat Modern menjadi dua kelompok yaitu yang menggunakan pendekatan ilmu sosial, dan yang menggunakan pendekatan doktrinal. Kelompok pertama adalah yang menggunakan metode etnografi hukum untuk mengetahui hukum-hukum adat yang berlaku di berbagai tempat. Etnografi tersebut memperlihatkan karakteristik lokal dan beragam dari hukum adat. Van Vollenhoven masih masuk kedalam kelompok ini sekalipun ia sudah mulai memperkenalkan aspek-aspek umum pada hukum adat seperti kategori atau pembidangan dalam hukum adat.

Kelompok kedua dari eksponen Ilmu Pengetahuan Hukum Adat Modern adalah yang digagas oleh Ter Haar. Kelompok ini bermaksud mengembangkan pendekatan positivistik dalam studi hukum adat agar menjadi disiplin yang mandiri dari ilmu hukum positif yang umum, dan dari pendekatan ilmu-ilmu sosial. Ter Haar dianggap sebagai tokoh sentral dalam pengembangan Ilmu Pengetahuan Hukum Adat Modern. Teorinya mengenai keputusan (beslissingen leer) dilihat sebagai manifestasi dari pendekatan positivistik. Oleh teori ini hukum adat dilihat sebagai benda yang berwujud dan konkret yaitu putusan pengurus adat. Putusan diambil dengan menerapkan nalar deduktif yakni pengurus adat mempertimbangkan sistem perikatan sosial dan nilai-nilai yang dipertahankan masyarakat, dalam menyelesaikan perselisihan. ${ }^{32}$

Sekalipun berbeda dalam mendefiniskan hukum adat, kedua kelompok dalam Ilmu Pengetahuan Hukum Adat Modern ini dianggap sama-sama menggunakan perspektif pemikiran hukum Barat (western legal thoughts) dalam menjelaskan hukum adat. Salah satu contoh

\footnotetext{
30 Pemikiran Koesnoe mengenai Ilmu Hukum Adat Positif dapat dijumpai pada sejumlah tulisannya diantaranya dalam, "Catatan-catatan terhadap Hukum Adat dewasa ini (buku), "Dasar-dasar formal Ilmu Hukum Adat (makalah), "Menuju kepada penyusunan Teori Hukum Adat: prinsip dan sistem (makalah), dan "Ilmu Adat sebagai salah satu khasanah Ilmu Hukum Nasional (makalah).

31 Joeni Arianto Kurniawan, "Gagasan Membangun (kembali) Ilmu Hukum Normatif: Konseptualisasi Mohammad Koesnoe tentang Hukum Adat sebagai Dasar Hukum Nasional Indonesia, dalam Joeni Arianto Kurniawan (ed.), 2013, Mohammad Koesnoe dalam pengembaraan gagasan hukum Indonesia, Epistema Institute\&HUMA, Jakarta., hlm. 103.

32 Soepomo, 2000, Bab-bab tentang Hukum Adat, Pradnya Paramita, Jakarta, hlm. 31.
} 
nyata dari perspektif ini adalah pemikiran bahwa hukum adat itu harus merupakan sesuatu yang bisa dibuktikan keberadaanya (positif). Ia harus berupa benda yang dapat diamati (observable). Menampilkan hukum adat dalam wujudnya yang nyata lewat kasus dan putusan, merupakan pembuktian keberadaan hukum adat.

Sebagai perbandingan, Van Vollenhoven mengelompokan kajian ilmuwan Barat mengenai hukum adat kedalam dua yaitu sebelum dan sesudah abad ke-20. Kedua kelompok tersebut sama-sama mengumpulkan atau mengkompilasi hukum adat, namun dengan kesadaran yang bertolak belakang. Kompilasi oleh kelompok tersebut masih didasarkan pada kesadaran bahwa hukum adat bersifat primitif dan karena itu harus ditiadakan dengan jalan unifikasi dengan cara memberlakukan hukum Barat. Kelompok kedua menentang kesadaran ini dengan melakukan kompilasi yang didasarkan pada semangat memahami dan menghormati sifat-sifat ke-Timuran.

Ilmu Hukum Adat Nasional berkembang setelah Indonesia menjadi bangsa merdeka. Namanama seperti Soepomo, Hazairin, Djodjodigoeno, dan Muhammad Koesnoe adalah pelopor untuk Ilmu ini. Para eksponen ilmu ini menginginkan studi hukum adat kembali ke Ilmu Adat disatu sisi dan menghilangkan pengaruh Ilmu Pengetahuan Hukum Adat Modern pada sisi yang lain. Keinginan untuk bersandar pada Ilmu Adat bukan semata-mata karena sentimen anti pemikiran Barat tapi karena alasan obyektif bahwa hukum adat bukan seperti yang dikonsepsikan oleh para pengguna pemikiran hukum Barat. Hukum adat bukan aturan-aturan substantif yang berkedudukan sebagai pedoman sehingga bersifat tetap dan mapan serta berbeda dari satu tempat ketempat lainnya. Meminjam pandangan Ilmu Adat, Ilmu Hukum Adat Nasional memahami hukum adat sebagai asas-asas yang bersifat umum. Dalam membuat keputusan, para pengurus adat tidak mengacu pada norma substantif melainkan pada asas-asas yang penerapannya bervariasi mengikuti kebutuhan setempat.

Teorisasi hukum adat sebagai asas-asas umum, bukan norma-norma substantif yang berbeda dari satu tempat ketempat lainnya, didorong juga oleh upaya untuk menyuntikan pemikiran kebangsaan pada studi hukum adat untuk membuka jalan menjadikan hukum adat sebagai landasan sistem hukum nasional. ${ }^{33}$ Agar hukum adat bisa menjadi representasi citra rasa atau jiwa bangsa Indonesia maka ia perlu bersifat umum, berlaku pada banyak atau semua tempat di Indonesia. Karena itu studi hukum adat perlu menggali dan membicarakan elemen-elemen yang bersifat umum dari hukum adat yaitu asas. Untuk melengkapinya perlu dikembangkan teori atau ajaran-ajaran umum mengenai hukum adat. Dengan kata lain, sisi yang hendak dicermati pada hukum adat bukanlah aspek empiriknya melainkan dimensi teoritis-filosofisnya.

Pemikiran bahwa hukum adat harus berwawasan kebangsaan dan karena itu harus bersifat umum pada akhirnya menyebabkan Ilmu Hukum Adat Nasional memiliki kemiripan dengan Ilmu Pengetahuan Hukum Adat Modern yang menggunakan pendekatan doktrinal. Sekalipun keduanya bisa dibedakan karena yang satu menggunakan metode induktif dan yang lain deduktif, namun memiliki kemiripan karena samasama menggunakan perspektif posivistik. Keduanya mengarah ke pengembangan jusriprudence dalam studi hukum adat yang mengasumsikan hukum adat merupakan sistem yang tersusun atas sejumlah unsur. Unsur-unsur yang ada berelasi satu sama lain secara mekanistik dan berlangsung selaras. Itu sebabnya, walau Ilmu Hukum Adat Nasional mendasarkan perkembangannya pada Ilmu Adat, namun dengan pandangan-pandangan seperti diatas

\footnotetext{
33 Muhammad Busar, Op.cit., hlm. 120, lihat juga Herman Slaats, et al., Op. cit., hlm. 21, David Bourchier, "Positivism and Romantism in Indonesian Legal Thought, dalam Timothy Lindsey (ed.), 1999, Indonesia Law and Society, The Federation Press, Australia, dan Khudzaifah Dimyati, 2004, Teorisasi Hukum: studi tentang perkembangan pemikiran hukum di Indonesia 1945-1990, Muhammadyah University Press, Surakarta.
} 
ia lebih tepat dikategorikan sebagai Ilmu Hukum Adat Positif. ${ }^{34}$

\section{Pandangan Dasar Ilmu Hukum Adat Positif}

Salah satu cara memahami Ilmu Hukum Adat Positif adalah dengan mengetahui pandanganpandangan dasarnya. Pandangan-pandangan dasar itu sekaligus berisikan dalil-dalil yang dianggap sebagai kebenaran. Sejauh yang bisa ditemukan pada tulisan Ter Haar, Koesnoe dan ilmuwan hukum adat lainnya, pendekatan positivistik memiliki dua pandangan dasar yaitu mengenai susunan (tatanan) hukum adat dan cara bekerjanya. Secara konseptual, pandangan dasar yang pertama berimplikasi pada pandangan dasar kedua. Dalam pandangan dasar yang kedua terdapat penjelasan terkait penalaran mengenai bagaimana hukum adat dioperasikan.

\section{a. Susunan (tatanan) Hukum Adat}

Ilmu Hukum Adat Positif berpendapat bahwa hukum adat yang lokal dan beragam, masing-masing memiliki unsur yang tersusun dan tertata karena melangsungkan relasi sistematik. Unsur-unsur tersebut terdiri dari yang bersifat umum dan karena itu dapat diberlakukan pada sejumlah tempat atau kasus, dan yang sifatnya konkret karena itu hanya berlaku untuk tempat atau kasus tertentu. Karena masing-masing unsur terhubung dengan logika dan mekanisme sistemik, membuat hukum adat dapat diklasifikasikan sebagai suatu sistem. Kutipan pernyataan dibawah ini menggambarkan hal tersebut:

"Sebagai sistem hukum, Hukum Adat memenuhi syarat suatu sistem, ia mempunyai konsepsi-konsepsi dasar, mempunyai unsur-unsur, bagianbagian, runtut atau konsisten, dan berkelengkapan, yang kesemuanya itu merupakan suatu keseluruhan yang terangkai". ${ }^{35}$

Pada umumnya para ahli hukum adat berpandangan sama bahwa sistem hukum adat memiliki tiga unsur yaitu konsepsi dasar, asas, dan norma. Ketiganya tersusun secara hirarkis yang sekaligus menjelaskan kekuatan validitas. Unsur konsepsi dasar berada pada tingkatan tertinggi pada hirarki tersebut, disusul asas, dan unsur norma pada kedudukan terendah. Konsep dasar dan asas bersifat abstrak dan karena itu dapat berlaku umum (beberapa tempat dan kasus). Adapun norma, bersifat konkret dan karena itu berlaku hanya pada tempat dan kasus tertentu.

Koesnoe berusaha membuktikan keberadaan hukum adat sebagai sistem dengan menunjukan beberapa contoh konkret. Dalam sejumlah kesempatan, masyarakat Minangkabau dan Bali, dijadikan sebagai contoh. Pertama-tama ditunjukan unsur-unsur (Koesnoe menggunakan istilah kategori) dalam hukum adat pada kedua masyarakat tersebut. Di Minangkabau dikenal dua unsur besar yaitu adat yang berbuhul (bertali) mati, dan adat yang berbuhul sintak. ${ }^{36}$ Adat berbuhul mati disebut juga sebagai adat sabana adat. Ini adalah kategori adat yang sifatnya kekal karena tidak akan berubah karena perbedaan waktu dan tempat. Itu sebabnya adat ini disebut juga sebagai Adat Alam. Komunitas adat menjadikannya sebagai inspirasi untuk menyelenggarakan tertib kemasyarakatan.

Adapun adat berbuhul sintak bersifat sebaliknya yaitu adat yang tunduk pada perubahan-perubahan. Adat ketegori kedua

\footnotetext{
Herman Slaats, et al., Op.cit., hlm. 3.

Lihat dalam R.H., Soedarso, "Studi hukum adat, dalam M. Syamsudin et al., 1998, Hukum Adat dan Modernisasi Hukum, Fakultas Hukum Universitas Islam Indonesia, Yogyakarta. hlm. 7.

36 Mohammad Koesnoe, 1979, Catatan-catatan terhadap Hukum Adat dewasa ini, Airlangga University Press, Surabaya, hlm. 55, dan lihat juga Mohammad Koesnoe, 1998, "Menuju kepada Penyusunan Teori Hukum Adat, dalam M. Syamsudin, et al., Hukum Adat dan Modernisasi Hukum, Fakultas Hukum Universitas Islam Indonesia, Yogyakarta, hlm. 45.
} 
ini sering juga disebut sebagai Adat Pusaka. Sekalipun demikian, komponen Adat Pusaka berubah dengan gradasi yang berubah. Ada yang berubah dengan tidak mudah karena kedudukannya sebagai konstitusi atau hukum dasar. Bagian yang lain berubahubah mengikuti perbedaan waktu, tempat dan keadaan. Karena perbedaan tersebut Adat Pusaka terbagi menjadi tiga yaitu adat istiadat, adat nan teradat, dan adat nan diadatkan. Adat istiadat tergolong tidak mudah berubah karena merupakan prinsip dan pandangan dasar adat. Sedangkan adat nan teradat dan adat nan diadatkan relatif mudah berubah. Menurut asalnya, Adat Pusaka diwariskan oleh para leluhur kepada generasi berikutnya.

Pembagian kategori adat oleh Orang Minangkabau diatas, yang mempertimbangkan asal muasal dan cakupan keberlakuan, mengingatkan kita pada pemikiran Aliran Hukum Alam mengenai kategori hukum. Thomas Aquinas (12251274) membagi hukum kedalam tiga kategori yaitu hukum abadi (lex divina), hukum kodrat (lex naturalis), dan hukum positif (lex positivis). ${ }^{37}$ Serupa dengan adat yang berbuhul mati, Hukum Abadi dan Hukum Kodrat bersifat alamiah dan karena itu tidak tergerus oleh perubahan keadaan. Keduanya berasal dari Tuhan. Adapun hukum positif, sebagai hasil usaha manusia memahami dan menerapkan Hukum Abadi dan Hukum Kodrat, dapat diubah oleh keadaan.

Hukum Adat Orang Bali mengenal tiga kategori yang tersusun secara hirarkis yaitu gama, sima, dan perarem. Gama berada pada tingkatan (niveau) yang lebih tinggi, bersifat abstrak dan karena itu berlaku umum bagi semua Orang Bali. Sima adalah adat yang berlaku secara terbatas pada desa atau sekelompok desa tertentu. Perarem lebih spesifik lagi karena hanya merupakan keputusan dari suatu rapat-rapat adat atas suatu perselisihan. Para pihak yang terlibat dalam perselisihan terikat kepada keputusan tersebut. $^{38}$

Menurut Koesnoe kategori-kategori merupakan unsur formal dari hukum adat yang mutlak harus ada, secara sistematik dan padu membentuk kerangka yang menjadi sandaran bagi hukum adat bekerja. ${ }^{39}$ Koesnoe menggunakan istilah 'sistem borongan' untuk mencirikan sistem hukum adat meskipun penjelasannya mengenai hal ini sulit untuk dipahami.

Kedudukan hukum adat sebagai sistem juga dibahas dalam pemikiran yang membahas pembidangan kedalam topik dalam hukum adat. Dari sejak abad kesembilan belas sampai saat ini bahasan hukum adat masing berupa bidang-bidang berikut, yaitu:

1. Susunan persekutuan hukum

2. Hukum keluarga

3. Hukum perkawinan

4. Hukum waris

5. Hukum tanah dan air

6. Hukum perutangan, dan

7. Delik adat

Kategori atau bidang bahasan Susunan Persekutuan Kukum ditaruh di awal untuk menjadikannya sebagai landasan enam kategori berikutnya, terutama yang kedua sampai keempat. Susunan Persekutuan Hukum yang dapat didasarkan pada ikatan teritori, keturunan (genealogis), atau campuran keduanya, berpengaruh pada hukum keluarga, perkawinan, dan waris. Status hak dan kewajiban seseorang (hukum

\footnotetext{
Lihat dalam Sumaryono, 2002, hlm. 137, dan Darji Darmodiharjo, et al., 2004 Pokok-pokok Filsafat Hukum: Apa dan Bagaimana Filsafat Hukum Indonesia, Gramedia Pustaka Utama, Jakarta, hlm. 106.

38 Mohammad Koesnoe, 1979, Op.cit., hlm. 14.

39 Mohammad Koesnoe, 1998, Op.cit., hlm. 46.
} 
keluarga), bentuk-bentuk perkawinan, dan pembagian warisan, ditentukan oleh ikatan persekutuan. Pengaruhnya juga sampai pada penentuan hubungan hak persekutuan atau anggotanya dengan tanah dan air. ${ }^{40}$ Pada masyarakat adat patrilineal atau matrilineal, hanya orang-orang yang mempunyai hubungan menurut garis keturunan ayah atau ibu (unilineal), yang dapat mempunyai hak atas tanah. ${ }^{41}$ Selanjutnya Van Vollenhoven menjadikan ketujuh kategori atau bidang bahasan diatas sebagai ukuran untuk membagi Indonesia kedalam 19 lingkaran hukum adat (adatrechtskring). Setiap lingkaran hukum adat memiliki ketujuh kategori tersebut.

Pembagian kedalam lingkaran hukum adat sebenarnya merupakan bagian dari proses menemukan unsur-unsur umum dalam hukum adat. Ketujuh kategori tersebut adalah hal-hal yang dianggap ada pada semua persekutuan hukum adat, terlepas dari masih adanya hal-hal khas yang hanya dijumpai pada satu atau beberapa persekutuan. Unsurunsur umum lewat Dalam masing-masing kategori hukum adat tersebut selanjutnya berkembang konsepsi dasar dan asas. Dalam hukum perikatan, seluruh persekutuan hukum adat dianggap menerapkan asas yang sama untuk perikatan jual-beli, dan panjer atau tanda ikat. ${ }^{42}$

\section{b. Cara Hukum Adat Bekerja}

Penanda utama positivisme pada studi hukum adat bukan pada pandangan bahwa hukum adat harus berbentuk tertulis tetapi pada penalaran untuk menjelaskan tautan antar unsur dalam sistem hukum adat. Nalar mengenai tautan itu selanjutnya digunakan untuk mengambil keputusan-keputusan adat, baik dengan atau tanpa adanya perselisihan.
Tindakan merespon kemunculan persoalan atau perselisihan dan menyelesaikannya dengan menggunakan nalar tertentu merupakan jelmaan dari sistem hukum adat yang bekerja. Nalar yang digunakan merupakan ciri pembeda cara bekerja sistem hukum adat dengan sistem-sistem sosial lainnya.

Dengan pandangan dasar bahwa hukum adat adalah suatu sistem yang unsur-unsurnya tersusun secara hirarkis dan sistematik karena satu sama lain tidak terlibat dalam pertentangan, membuat hukum adat bekerja dengan bantuan nalar deduktif. Nalar deduktif mengandaikan adanya unsurunsur tertentu yang abstrak, umum dan tetap yang menjadi rujukan dalam mengambil keputusan. Mengenai unsur-unsur ini ada perbedaan antara eksponen Ilmu Pengetahuan Hukum Adat Modern dengan eksponen Ilmu Hukum Adat Nasional.

Menurut Teori Keputusan dari Ter Haar, para pengurus hukum adat (kepala desa, hakim perdamaian desa, wali tanah, pegawai-pegawai agama dan desa) dan hakim-hakim pengadilan negara, membuat keputusan adat dengan berpatokan pada pedoman yang bersifat tetap dan mantap. Pedoman tersebut adalah norma-norma adat yang bersifat konkret dan spesifik mengenai hal-hal tertentu seperti pembagian harta gono-gini, hak waris anak angkat, dan hak menebus tanah gadai. Aturan-aturan konkret ini dapat diterapkan untuk menyelesaikan perkara-perkara adat pada semua kelompok masyarakat adat. Sifatnya yang berlaku umum membuat aturan-aturan ini disebut sebagai hukum adat substantif. ${ }^{43}$ Pemikiran untuk menghadirkan hukum adat substantif

Soepomo, Op.cit., hlm. 25

Rianto Adi, et al., 1998, Pola Penguasaan tanah masyarakat tradisional dan problema pendaftaran tanah, studi kasus di Sumatera Barat, Kalimantan Tengah, dan Nusa Tenggara Barat, Laporan Penelitian, Pusat Kajian Pembangunan Masyarakat Atma Jaya dan Badan Pertanahan Nasional, Jakarta, hlm. 12.

42 Soepomo, Op.cit., hlm. 26-27. 
tidak terlepas dari keinginan Ter Haar untuk menyusun jurisprudence hukum adat dengan cara menentukan garis-garis hukum adat yang bersifat tetap.

Para eksponen Ilmu Hukum Adat Nasional mempersoalkan pandangan Ilmu Pengetahuan Hukum Adat Modern diatas dengan mengatakan bahwa dalam hukum adat tidak dikenal adanya pre-existing norm seperti yang tercermin pada hukum adat substantif. Keputusan-keputusan adat tidak diambil dengan mengacu pada norma-norma adat yang telah lebih dulu ada dan berperan sebagai pedoman. Dalam praktiknya, keputusan diambil dengan mengacu pada asas-asas, bukan pada norma. Hukum adat bekerja dengan asas-asas pokok aja. Asasasas inilah yang bersifat umum dan tetap. Koesnoe mengatakan, "Praktik peradilan adat di desa-desa...mengadili suatu perkara adat...juga berpedoman kepada asasasas saja, yang kemudian setelah diolah dan disesuaikan dengan waktu dan tempat keadaan, diwujudkan dalam bentuk keputusan yang konkret'. Dengan menggunakan putusan kasasi tahun 1955 mengenai pembagian risiko perubahan nilai rupiah dalam gadai tanah, putusan kasasi tahun 1957 mengenai penjualan tanah tanpa izin pemiliknya, dan putusan Pengadilan Negeri Malang tahun 1973 mengenai pembagian harta gono-gini, Koesnoe menyimpulkan asas-asas dalam hukum adat yaitu pantas, patut, rukun, dan laras, sesuai dengan keadaan zaman, dan rasa keadilan. ${ }^{44}$

Asas-asas tersebut digunakan sebagai pertimbangan untuk memutuskan apakah terjadi atau tidak terjadi pelanggaran adat. Bila diputuskan terjadi pelanggaran adat selanjutnya disebutkan substansi hukum adat yang dilanggarnya atau hak dan kewajiban yang didapatkan atau diemban. Cara menerapkan asas-asas tersebut berbedabeda menurut tempat dan keadaan. Koesnoe memberikan penjelasan panjang lebar untuk asas rukun, patut, dan laras.

Substansi asas rukun adalah orientasi hidup bersama dalam satu lingkungan dengan tujuan mencapai hidup aman, tentram dan sejahtera. Orientasi ini didasarkan pada alasan bahwa setiap orang memerlukan satu sama lain. Satu modal besar untuk memiliki orintasi hidup yang seperti itu adalah menjauhkan pergaulan sosial dari pertimbangan untung rugi. Sebaliknya, harus dikembangkan perasaan saling mengerti, menerima, dan memaafkan kesalahan atau kekurangan orang lain. Asas rukun merupakan bagian dari ajaran berkehendak dan berkarya bersama. Intisari dari ajaran berkendak bersama adalah musyawarah untuk mufakat, sedangkan ajaran berkarya bersama adalah gotong royong atau tolong menolong.

Asas patut berkaitan dengan kesusilaan, mengenai perbuatan baik dan buruk. Untuk bisa mengenali perbuatan baik atau buruk, digunakan akal atau pikiran sehat (akal budi). Karena menyangkut kesusilaan, asas ini mempertimbangkan kualitas pihakpihak yang terlibat dengan memperhatikan kehormatan atau harga diri yang bermuara pada keluhuran sebagai manusia. Salah satu cara untuk menjaga harga diri adalah dengan mencegah seseorang dipojokan oleh rasa malu. Keragaman penerapan asas ini salah satunya disebabkan oleh perbedaan penekanan pada kesusilaan dan akal sehat. Penekanan pada akal sehat memunculkan suatu istilah yang lebih tepat, yaitu layak.

Asas yang terakhir yaitu laras menunjuk pada proses menghasilkan putusan 
yang secara optimal bisa memenuhi rasa estetik para pihak dan masyarakat. Karena itu ajaran laras menunjuk pada situasi setelah putusan diambil dengan memperhatikan penerimaan para pihak dan masyarakat. Putusan yang mengandung ajaran laras adalah yang tidak menyebabkan perselisihan lanjutan karena para pihak atau masyarakat tidak memandang putusan tersebut sebagai jawaban. Agar bisa menjawab keinginan tersebut, keputusan sebaiknya diambil dengan menggunakan kebijaksanaan yaitu belajar dari pengalaman-pengalaman masa sebelumnya. Putusan-putusan masa sebelumnya diperhatikan bukan untuk ditiru melainkan untuk dipedomani, karena perbedaan waktu dan tempat menentukan isi putusan. ${ }^{45}$

\section{Mempersoalkan Dalil-Dalil Ilmu Hukum} Adat Positif

Dari sudut ilmu pengetahuan, dorongan pokok untuk membangun pendekatan positivistik dalam studi hukum adat ialah mencari kejelasan mengenai apa yang dimaksudkan dengan hukum adat, dan bagaimana ia bekerja. Formulasi pandangan ini diharapkan dapat mendatangkan kepastian bagi pihak-pihak yang berkepentingan terhadap hukum adat di tengah-tengah realitas hukum adat yang beragam. Namun tidak bisa disangkal bahwa ada dorongan lain dibaliknya yaitu motif mengadvokasi hukum adat. Di era kolonialisme agenda advokasinya adalah menolak pemberlakuan hukum Barat pada golongan Pribumi yang berkonsekuensi pada pengakuan keberlakuan hukum adat. Suatu strategi efektif untuk menjalankan agenda advokasi ini adalah dengan menyediakan formulasi pengetahuan hukum adat yang aplikatif bagi administrator pemerintahan kolonial. Sedangkan di era kemerdekaan agenda advokasi adalah menempatkan hukum adat sebagai landasan bagi sistem hukum nasional. Caranya adalah dengan mengkonstruksi hukum adat sebagai instrumen pemersatu bangsa, yang mengandung jiwa bangsa, dan dapat diberlakukan secara nasional. Dorongan-dorongan di atas memberi andil pada pendirian eksponen Ilmu Hukum Adat Positif untuk tidak tergantung atau bahkan menggunakan pendekatan ilmu-ilmu sosial. Baik Ilmu Pengetahuan Hukum Adat Modern yang menggunakan pendekatan doktrinal maupun Ilmu Hukum Adat Nasional, memilih untuk tidak menggantungkan diri pada ilmu-ilmu sosial. Pendirian ini melahirkan praktik penyelenggaraan studi hukum adat positivistik terpisah dengan yang menggunakan pendekatan ilmu sosial. ${ }^{46}$ Karena bersifat deduktif normologis, penggunaan kasus dalam studi positivistik bersifat instrumental yaitu sebagai objek untuk menguji atau menerapkan konsep-konsep dasar atau asas, dengan tujuan menghasilkan kesimpulan atau keputusan.

Motif advokasi yang berakibat pada ketidaktertarikan untuk memahami kasus-kasus dari lensa sosial pada akhirnya memunculkan sederet pertanyaan mendasar pada pendekatan ini. Dengan tidak memahami atau mendeskripsikan kasus-kasus, bagaimana pendekatan ini bisa menjelaskan objeknya dengan akurat? Metode apa yang dikembangkan oleh pendekatan ini untuk bisa mengikuti perkembangan objeknya, yaitu hukum adat yang secara alamiah berkarakter dinamis?

Tulisan ini memulai suatu ikhtiar untuk menjawab secara serius pertanyaan-pertanyaan diatas. Pada kesempatan ini metode yang dipilih adalah dengan memeriksa satu konsep penting dalam studi hukum adat yaitu 'hukum adat'. Tulisan ini memeriksa bagaimana pendekatan positivistik meninjau ulang pengertian hukum adat untuk merespon atau mengkontekstualisasi dengan perkembangan empirik. Untuk memperjelas deskripsi, akan dibandingkan dengan upaya serupa oleh ilmu-ilmu sosial.

Dalam sejumlah forum ujian disertasi

45 Ibid., hlm. 55

46 Herman Slaats, et al., Op.cit., hlm. 22\&43. 
di Fakultas Hukum Universitas Gadjah Mada penguji bertanya kepada mahasiswa apakah masih ada masyarakat adat dilokasi penelitian. Lewat pertanyaan itu, penguji sebenarnya sedang mempertanyakan apakah aturan yang diteliti merupakan hukum adat atau bukan. Pertanyaan dikemukakan semata-mata karena lokasi penelitian berada di Pulau Jawa, terutama wilayah perkotaan, yang notabene dikenal bukan lagi sebagai 'habitat' masyarakat hukum adat.

Pertanyaan di atas mewakili sebuah pemikiran dalam mengartikan istilah 'hukum adat'. Pemikiran tersebut mendalilkan bahwa hukum adat tidak bisa dipisahkan dari masyarakat hukum adat (MHA). Alasannya karena MHAmerupakan organisasi sosial selaku pengemban hukum adat. Organisasi sosial yang lain boleh jadi juga merupakan masyarakat hukum namun tertib hukumnya bukan didasarkan pada adat. Selain hukum adat petanda lain dari MHA yang membedakannya dengan masyarakat hukum $^{47}$ lainnya yaitu terbentuk secara alamiah karena tidak dibentuk oleh otoritas lain, dan para anggotanya diikat oleh identitas bersama. ${ }^{48}$ Namun demikian, MHA juga sama dengan masyarakat hukum lainnya karena mempunyai ukuran-ukuran yaitu memiliki aturan (rules), otoritas dengan kewibawaan menegakan aturan, wilayah, dan harta bersama.

Kesimpulan bahwa MHA adalah pengemban hukum adat sebenarnya bukan merupakan suatu pernyataan langsung. Kesimpulan tersebut didapatkan dari pemikiran yang mengaitkan secara erat MHA dengan hukum adat. Sebenarnya bila mengacu pada Pasal 75 Regeling Reglement 1848, yang membagi penduduk Hindia Belanda kedalam 3 golongan berdasarkan ras, hukum adat adalah aturan yang digunakan atau berlaku kepada
Golongan Bumiputra dan Golongan Timur Asing Non Tionghoa. Ketentuan seperti itu memancing orang seperti Van Vollenhoven mengartikan hukum adat dipakai oleh semua kelompok dalam Golongan Bumiputra termasuk lingkungan atau keluarga kerajaan. Akibatnya, peraturan raja-raja masuk kedalam cakupan hukum adat dan karena itu kerajaan juga termasuk pengemban hukum adat.

Pemikiran diatas tentu saja bertentangan dengan pandangan yang menjelaskan hukum adat sebagai suatu sistem seperti sudah dijelaskan sebelumnya. Menurut pandangan ini membicarakan hukum adat tidak mungkin melepaskannya dari MHA karena kategori pertama yang mendasari penjelasan atas kategori-kategori berikutnya adalah mengenai persekutuan masyarakat alias MHA. Dengan kata lain yang dijelaskan berikutnya mengenai hukum adat keluarga, perkawinan, warisan, tanah, dan delik, adalah aturannya persekutuan masyarakat. Pembahasan mengenai bentuk-bentuk persekutuan masyarakat, tidak memasukan (lingkungan) kerajaan sebagai tipe atau contoh. Literaturliteratur hukum adat tidak menjadikan keluarga kerajaan sebagai contoh dalam membahas susunan persekutuan hukum.

Karena tidak bisa dipisahkan dari MHA dengan penjelasan seperti di atas mengakibatkan status hukum adat menjadi tergantung pada perubahan-perubahan yang terjadi pada MHA. Sederhananya, bila suatu komunitas tidak lagi berkarakter sebagai MHA berdasarkan ukuranukuran yang disebutkan diatas, dengan sendirinya aturan yang menjadi landasan tertib sosialnya tidak lagi bisa dikualifikasi sebagai hukum adat. Sayangnya, pemikiran ini tidak memiliki penjelasan termasuk memberi nama tersendiri pada aturanaturan masyarakat hukum yang tidak berkualifikasi

\footnotetext{
47 Dalam literatur hukum adat masyarakat atau persekutuan hukum (rechtsgemeenschap) diartikan sebagai suatu kelompok manusia yang anggota-anggotanya merasa terikat satu sama lain karena adanya rasa tanggung jawab bersama, dan hidup dalam tata hukum yang sama. Masyarakat hukum memiliki sejumlah ciri umum yaitu memiliki tata hukum, otoritas dengan kuasa untuk memaksa, harta kekayaan, dan ikatan batin diantara anggotanya (Sudiyat, et al., 1978:7-8; Rikardo Simarmata, 2006, Pengakuan hukum terhadap Masyarakat Adat di Indonesia, Regional Initiative on Indigenous Peoples-UNDP, Jakarta, hlm. 3).

48 Rikardo Simarmata, 2006, Pengakuan hukum terhadap Masyarakat Adat di Indonesia, Regional Initiative on Indigenous Peoples-UNDP, Jakarta, dan lihat Rikardo Simarmata, et al., 2017, Masyarakat hukum Adat sebagai Subyek Hukum, Kecakapan hukum masyarakat hukum adat dalam lapangan hukum privat dan publik. the Samdhana Institute, Yogyakarta.
} 
sebagai MHA.

Menariknya, sekalipun pertanyaanpertanyaan penguji kepada mahasiswanya seperti disebutkan di atas diajukan berkali-kali, dalam realitasnya riset-riset serupa terus diproduksi. Aturan-aturan mengenai transaksi tanah, perkawinan, warisan, dan utang-piutang yang masih berlaku pada komunitas-komunitas yang tertib sosialnya sebagian sudah menyandarkan diri pada hukum negara, baik yang hidup di perkotaan maupun pedesaan, terus menjadi objek riset. Ini menandakan bahwa aturan-aturan tersebut dianggap sebagai hukum adat.

Praktik ini bisa saja dipahami sebagai bentuk ketidakkonsistenan kalangan akademisi. Namun ini bisa juga suatu fakta sudah berurat berakarnya penggunaan pendekatan biner atau pendekatan bipolar dalam studi hukum adat. Oleh pendekatan yang esensialis ini, semua aturan yang berlaku dalam masyarakat atau negara selalu bisa dikenali sebagai hukum negara, hukum adat atau hukum agama. Karena itu, bila suatu aturan bukan merupakan hukum negara atau hukum agama, dengan sendirinya berstatus sebagai hukum adat. ${ }^{49}$ Pendekatan ini tidak membayangkan bahwa suatu aturan dapat merupakan perpaduan atau percampuran berbagai elemen sistem hukum sehingga tidak dapat lagi dengan mudah dikategorikan sebagai hukum negara atau hukum adat. Sikap untuk menganggap aturanaturan yang dihasilkan oleh kelompok masyarakat yang tidak tergolong sebagai MHA sebagai hukum adat, sekalipun pada saat yang sama masih dianut pemikiran bahwa pengemban hukum adat adalah MHA, menggambarkan masih sulitnya para ilmuwan hukum adat melepaskan diri dari pengaruh pendekatan biner tersebut.
Pendekatan biner juga mempengaruhi Van Vollenhoven dalam merumuskan hukum adat. Hukum adat dimaknainya sebagai Native Law yang sudah bercampur dengan elemen-elemen hukum agama. $^{50}$ Sekalipun sudah bercampur dengan elemen-elemen hukum agama, Van Vollenhoven tetap menamai aturan-aturan tersebut sebagai hukum adat.

Kesadaran bahwa hukum adat menerima atau sudah bercampur dengan elemen-elemen hukum agama berkembang terus semasa Indonesia merdeka. Seminar Hukum Adat dan Pembinaan Hukum Nasional yang diselenggarakan pada tahun 1975 atas kerjasama Badan Pembinaan Hukum Nasional dan Universitas Gadjah Mada mengartikan hukum adat sebagai "hukum Indonesia asli yang tidak tertulis dalam bentuk peraturan perundangundangan yang disana-sini mengandung unsur agama". Definisi ini dengan terang mengakui bahwa hukum adat mengadopsi elemen hukum negara dan menjadikannya bagian integral dari sistem hukum adat.

Akan tetapi, sekalipun menyadari sudah dipengaruhi atau menerima pengaruh dari elemen sistem hukum agama, aturan-aturan tersebut masih dikualifikasi sebagai hukum adat. Penggunaan istilah untuk menamai pengembannya yaitu 'Indonesia asli' menyiratkan tidak lagi harus berkualifikasi sebagai MHA, tetapi cukup sebagai masyarakat hukum. Dengan tidak diperkenalkannya istilah lain untuk menamai hukum adat yang sudah menerima pengaruh dari elemen sistem hukum agama tersebut, pandangan ini juga terperangkap kedalam pendekatan biner. Menariknya, definisi ini mereduksi realitas karena melihat hukum adat hanya menerima pengaruh dari hukum agama,

49 John F. McCarthy, "Between Adat and State: Institutional Arrangements on Sumatra's Forest Frontier", Human Ecology, Vol. 33, No. 1, February 2005, Fitzpatrick, Daniel, "Land, custom, and the state in the post-Suharto Indonesia: a foreign lawyer's perspective, dalam Jamie S. Davidso, et al., 2007, The Revival of Tradition in Indonesian Politics: the deployment of adat from colonialism to indigenism. London and Routledge, New York; Rikardo Simarmata, "Relevansi Menggagas Studi Kontemporer Hukum Adat”, Makalah, Disampaikan pada Lokakarya Reorientasi Pengajaran dan Studi Hukum Adat, kerjasama Epistema Institute dan Fakultas Hukum Universitas Gadjah Mada, Yogyakarta, 7-8 Maret 2013, dan Rikardo Simarmata, "Menyoal Pendekatan Binar dalam Studi Adat, LSD, Vol. V, No. 2, June-December, 2013.

50 Istilah Native menunjuk pada penduduk asli atau Pribumi. Sedangkan istilah Agama menunjuk pada yang disebut sebagai Agama Dunia seperti Islam, Kristen, Hindu, dan Budha. Agama-agama ini disebut sebagai sesuatu yang diimpor Holleman, J.F. (ed.), 1981, Van Vollenhoven on Indonesian Adat Law, Martinus Nijhoff, The Hague. hlm. 5. 
tidak termasuk dari hukum negara. Ini suatu bukti lain pengaruh pendekatan biner khususnya yang menghadap-hadapkan hukum adat dengan hukum negara.

Selain mengaitkan dengan pengembannya, segi lain dari definisi hukum adat oleh pendekatan positivistik adalah mengenai bentuk. Sebagian ilmuwan hukum adat memahami hukum adat selalu berbentuk tidak tertulis. Sebagian yang lain tidak setuju dengan pendapat ini dengan mengatakan bahwa hukum adat dapat berbentuk tertulis maupun tidak tertulis. Untuk yang tertulis ada yang membatasinya tidak dalam bentuk peraturan perundang-undangan. ${ }^{51}$ Rumusan pengertian hukum adat oleh Seminar Hukum Adat yang disebutkan di atas, mengadopsi pandangan ini. Persyaratan tidak dalam bentuk peraturan perundang-undangan tentu saja dimaksudkan untuk membuat garis pembatas dengan hukum negara karena peraturan perundangundangan merupakan instrumen hukum negara. Meskipun hukum adat yang dituliskan dalam bentuk peraturan perundang-undangan tersebut masih bersubstansi adat, namun secara formil keberlakuannya sudah ditentukan oleh hukum negara. Singkatnya, hukum adat tersebut tidak lagi dibawah kendali otoritas adat melainkan sudah berpindah dibawah otoritas negara.

Pemikiran yang mensyaratkan hukum adat tertulis harus tidak dalam bentuk perundangundangan saat ini sedang dihadapkan pada perkembangan formalisasi hukum adat lewat legislasi khususnya produk hukum daerah. Sejak awal Era Reformasi bermunculan inisiatif daerah untuk mengakui secara formal hukum-hukum adat disejumlah daerah baik yang dihasilkan sebagai bagian dari proses politik maupun komitmen untuk melaksanakan amanah konstitusi dan peraturan perundang-undangan yang lebih tinggi. Mayoritas pengakuan atau formalisasi hukum adat terdapat dalam produk hukum daerah yang materi pokok nya mengenai pengakuan keberadaan MHA dan hak ulayat. Dalam produk-produk hukum daerah tersebut hukum adat ditentukan sebagai salah satu kriteria pengakuan keberadaan dan hak ulayat. Pengakuan hukum adat juga bisa ditemukan pada produk-produk hukum daerah yang mengatur mengenai lembaga adat dan penyelesaian sengketa berbasis adat. $^{52}$ Dalam produk-produk hukum daerah ini hukum adat menjadi materi pengaturan pokok karena secara konseptual lembaga adat dan penyelesaian sengketa berbasis adat mengandaikan adanya hukum adat. Lembaga adat berfungsi untuk melaksanakan dan menegakan hukum adat. Dengan kata lain, hukum adat memerlukan lembaga adat untuk bisa operasional. Penyelesaian sengketa berbasis adat merupakan arena penerapan hukum adat yang dilakukan oleh lembaga adat.

Cara produk-produk hukum daerah tersebut mengakui atau memformalisasi hukum adat bisa dikelompokan menjadi dua, yaitu, Pertama, dengan mengakui keberlakuan hukum adat di wilayah adat. Cara ini menyerahkan kewenangan kepada MHA bersangkutan untuk menentukan apa yang menjadi hukum adat. Sebagian besar menentukan hal tersebut dengan tidak menyebutkan nama dan sumber hukum adatnya. ${ }^{53}$ Sebagian kecil menyebutkan nama hukum adatnya namun tidak menyebut sumber tertulisnya. ${ }^{54}$ Kedua, dengan menuliskan apa yang ditentukan sebagai hukum adat. Sebagian produk hukum daerah menentukan

51 Djojodigoeno merupakan salah satu ahli hukum adat yang menganut pandangan ini. Beliau mengartikan hukum adat sebagai hukum yang tidak bersumber dari peraturan. Karena itu Djojodigoeno menolak jika peraturan raja-raja, peraturan desa, dan peraturan fiqih dikategorikan sebagai hukum adat. Alasannya karena aturan-aturan tersebut sudah berbentuk peraturan Djojodigoeno, M.M., 1958, Asas-asas Hukum Adat, Jajasan Badan Penerbit Gadjah Mada, Jogjakarta, hlm. 6-7.

52 Sebagai contoh Peraturan Daerah Provinsi Kalimantan Tengah No. 16/2008 sebagaimana diubah oleh Perda No. 1/2010 tentang Kelembagaan Adat Dayak di Kalimantan Tengah, Peraturan Daerah Khusus Provinsi Papua No. 20/2008 tentang Peradilan Adat di Papua, Perda Kabupaten Kapuas No. 3/2015 tentang Kelembagaan Adat di Kabupaten Kapuas, Perda Kabupaten Kepulauan Mentawai No. 11/2017 tentang Pengakuan dan Perlindungan Uma sebagai Kesatuan Masyarakat Hukum Adat di Kabupaten Kepulauan Mentawai, dan Perda Kabupaten Manggarai No. 1/2018 tentang Penyelesaian Sengketa Berbasis Adat.

53 Sebagai contoh Peraturan Daerah Provinsi Kalimantan Tengah No. 16/2008 sebagaimana diubah oleh Perda No. 1/2010 tentang Kelembagaan Adat Dayak di Kalimantan Tengah, dan Peraturan Daerah Khusus Provinsi Papua No. 20/2008 tentang Peradilan Adat di Papua. 
langsung rumusan hukum adat baik secara parsial maupun menyeluruh. Untuk pengakuan yang bersifat menyeluruh, hukum adat yang diakui sudah dalam bentuk kompilasi. ${ }^{55}$ Perumusan hukum adat dilakukan dengan dua cara yaitu dengan menyebutkannya didalam peraturan perundangundangan ${ }^{56}$ ataupun dengan menjadikannya sebagai lampiran. ${ }^{57}$

Formulasi mengenai pengertian hukum adat tertulis diatas tentu saja akan menyimpulkan bahwa norma-norma adat yang sudah dituliskan dalam produk hukum daerah sudah berstatus sebagai hukum negara. Argumennya, seperti sudah disebutkan, karena norma-norma tersebut secara formal sudah berada di bawah kendali otoritas negara. Menariknya, argumen tersebut tidak sepenuhnya didukung oleh fakta empirik. Beberapa produk hukum daerah dengan eksplisit mengatakan bahwa hukum-hukum adat yang diakui dan dilindungi keberadaanya oleh pemerintah daerah, dilaksanakan oleh para pengurus atau fungsionaris adat. $^{58}$

Pada formalisasi yang lebih dilatari oleh perasaan diperlakukan tidak adil dalam pemanfaatan sumber daya alam dan karena itu bertujuan untuk menciptakan peluang akses dan hak, lembaga-lembaga adat bahkan lebih berkuasa dalam melaksanakan dan menegakan produkproduk daerah. Dalam kasus serupa ini elit-elit adat dan pimpinan birokrasi seringkali berkongsi untuk meraih kepentingan pribadi dalam melaksanakan dan menegakan produk-produk hukum daerah yang mengakui hukum adat. ${ }^{59}$ Kedudukan otoritas adat yang tidak lagi menjadi subordinat negara tersebut dimungkinkan juga oleh semangat umum yang sedang berkembang bahwa saatnya hukum adat diatas hukum negara atau adat bebas dari pengaturan negara setelah masyarakat adat hanya menjadi penonton selama masa pemerintahan Orde Baru (1966-1998). ${ }^{60}$

Paparan diatas, mengenai dua segi dari cara mengartikan istilah hukum adat, yaitu pengemban dan bentuknya, memperlihatkan tidak akuratnya konsep hukum adat dalam menjelaskan realitas hukum adat yang terus berkembang. Pemikiran yang mendasari pengertian tersebut berpendirian bahwa jagat ketertiban diisi oleh hukum negara dan hukum adat, dengan tambahan hukum agama, dan keduanya mempertahankan eksistensinya masingmasing sekalipun mengalami perubahan-perubahan. Termasuk perubahan karena berlangsungnya perjumpaan antara kedua sistem hukum tersebut. Dalil inipun tidak mampu menjelaskan aturanaturan non negara yang masih terus dipertahankan dan diproduksi oleh komunitas-komunitas yang tadinya berstatus sebagai MHA namun berubah menjadi masyarakat hukum saja. Hal yang sama untuk hukum adat tertulis dalam bentuk peraturan

54 Sebagai contoh Perda Kabupaten Bulukumba No. 9/2015 tentang Pengukuhan, Pengakuan Hak, dan Perlindungan Hak Masyarakat Hukum Adat Ammatoa Kajang. Dakam Perda ini yang disebut sebagai hukum adat adalah Pasang ri Kajang yang berisi nilai dan aturan dengan fungsi sebagai tuntutan bagi kehidupan MHA Ammatoa Kajang (Pasal 1 angka 7).

55 Contoh produk hukum daerah yang menyebutkan sekaligus mengakui keberadaan hukum adat yang dikompilasi adalah Perda Kabupaten Sintang No. 12/2015 tentang Pengakuan dan Perlindungan Kelembagaan Adat dan Masyarakat Hukum Adat. Menurut Peraturan ini, kompilasi tersebut terdapat dalam Buku Adat Suku Dayak dan Buku Adat Suku Melayu (Pasal 4 ayat 2).

56 Sebagai contoh Perda Kabupaten Lebak No. 32/2001 tentang Perlindungan atas Hak Ulayat Masyarakat Baduy. Penjelasan Pasal 9 ayat (1) Perda ini menyebutkan tabu atau larangan dalam hukum adat Baduy kepada masyarakat luar Baduy yang dapat mengganggu atau merusak lahan dalam ulayat adat. Tabu atau larangan tersebut diantaranya menggembalakan hewan ternak berkaki empat, menangkap ikan dengan menggunakan racun, melakukan penggalian pasir atau batu, atau mengabil daun aren. Perda ini menentukan bahwa pelangaran atas tabu atau larangan tersebut menjadi perbuatan pidana. Dengan demikian penegakannya dilakukan oleh negara.

57 Sebagai contoh Perda Kabupaten Sintang No. 12/2015 tentang Pengakuan dan Perlindungan Kelembagaan Adat dan Masyarakat Hukum Adat.

58 Misalnya Perda Kabupaten Sintang No. 12/2015 (Pasal 5 ayat 2), dan Perda Kabupaten Merangin No. 8/2016 tentang Pengakuan dan Perlindungan Masyarakat Hukum Adat Margas Serampas (Pasal 9 ayat 2).

59 Lihat John F. McCarthy, 2006, The Fourth Circle A Political Ecology of Sumatra 's Rainforest Frontier, Stanford University Press, Stanford, California, Laurens Bakker, "Illegality for The General Good? Vigilantism and Social Responsibility in Contemporary Indonesia", Critique of Anthropology, Vol. 35, No. 1, Jamie S. Davidson, et al., 2007 The Revival of Tradition in Indonesian Politics: the deployment of adat from colonialism to indigenism, Routledge, London dan New York, dan Edward Aspinall, et al., 2011, The state and illegality in Indonesia, KITLV Press, Leiden.

60 Lihat Christopher Barr, et al., 2001, The Impacts of Decentralization on Forests and Forest-Dependent Communities in Malinau District, East Kalimantan, Center for International Forestry Research, Bogor, hlm.26. 
perundang-undangan yang lahir karena perjumpaan negara dengan adat. Untuk kasus yang pertama, pengertian ini tetap menganggap aturan-aturan tersebut sebagai hukum adat. Sedangkan untuk kasus yang kedua justru sebaliknya, menganggapnya sudah menjadi hukum negara.

Berbeda dengan studi hukum adat dengan pendekatan positivistik, studi hukum adat dengan pendekatan sosial, terutama antropologi hukum dan sejarah, telah lama menjaga tradisi melangsungkan diskursus mengenai pengertian hukum yang dibuat atau berasal dari rakyat (baca: hukum adat). Penggunaan data-data temuan lapangan memungkinkan diskursus tersebut menemukan dan mengenali pola, konstelasi, beserta dinamika sistem-sistem pengaturan (normative orders) yang bekerja dan mengendalikan masyarakat. Diskursus menunjukan bahwa hukum yang dibuat atau berasal dari rakyat, karena terus berdinamika baik karena didorong oleh faktor-faktor yang berasal dari dalam maupun dari luar, tidak berwajah tunggal. Dinamika menghasilkan perubahan pada hukum ini baik dari segi bentuk, substansi, maupun cara membuat dan menegakannya. Metode paling umum untuk melakukan perubahan itu yaitu dengan meminjam atau mengakomodir elemen-elemen sistem hukum lainnya seperti hukum agama atau hukum negara. ${ }^{61}$

Sikap ilmiah para ilmuwan sosial mendapati hukum yang dinamik dan berwajah banyak tersebut adalah dengan memunculkan ragam istilah. Istilah beragam merupakan konsekuensi dari penekanan pada hal tertentu sewaktu melakukan pendefinisian. Penekanan dilakukan pada dua aspek yaitu asalusul, ideologi, proses pembuatan, pelaksanaan/ pengadministrasian, dan substansi aturan.

Penekanan pada aspek asal-usul menemukan dua perbedaan hukum yaitu yang berasal dari rakyat yang dilawankan dengan hukum yang berasal dari kerajaan/negara . Hukum buatan atau yang berasal dari rakyat dinamai dengan people's law/folk law, sementara hukum buatan negara dinamai king's law/ lawyer's law/state law. ${ }^{62}$ Hukum adat (adat rechts) dianggap sebagai salah satu contoh hukum yang berasal dari rakyat. Secara etimologi, kata 'peoples' dan 'folk' berasal dari kata 'vulgus' yang diartikan rakyat kebanyakan yang menduduki kelas rendah dalam lapisan sosial. ${ }^{63}$

Penekanan pada aspek ideologis, dalam sejarahnya, pernah digunakan dalam konteks menjustifikasi kolonialisme dengan membedakan antara aturan yang mewakili dan tidak mewakili peradaban (baca: nilai kemanusiaan). Para pendukung kolonialisme memandang aturan-aturan yang menopang tertib sosial komunitas-komunitas kesukuan di negara jajahan belum mewakili peradaban dengan alasan tidak bersesuaian dengan paham kemanusiaan yang ditandai dengan pembolehan penggunaan kekerasan dalam menghukum pelaku dan keluarganya. Cara tersebut dianggap tidak menghormati martabat kemanusiaan seseorang. ${ }^{64}$ Kesimpulan ini membuat para pendukung kolonialisme menamai aturan ini sebagai savage law/primitive law/traditional law. Sebagai lawan dari savage law/primitive law/ traditional law adalah modern law yang menunjuk pada aturan-aturan yang dibuat oleh bangsa-bangsa Barat sebagai representasi dari peradaban yang sudah menjadikan kemanusiaan sebagai nilai yang harus dikandung oleh substansi aturan hukum. ${ }^{65}$ Dari segi kedudukan, savage law/primitive law/ traditional law dianggap sebagai subordinasi dari modern law. Savage law/primitive law/traditional law baru akan dinyatakan berstatus sebagai aturan yang mengikat dan karena itu memiliki daya laku,

61 John Griffiths, "What is Legal Pluralism?”, Journal of Legal Pluralism\& Unofficial Law, Vol. 24, 1986, Sally Engle Merry, "Legal pluralism", Law and Society Review, Vol. 22, No. 5, 1988, dan Ratno Lukito, 2008, Hukum Sakral dan Hukum Sekuler, Studi tentang Konflik dan Resolusi dalam Sistem Hukum Indonesia, Pustaka Alvabet, Jakarta.

62 G.C.J.J, Van den Bergh, "The Concept of Folk Law in Historical Context: A Brief Outline", dalam Alison Dundes Renteln, et al., 1994, Folk Law Essays in the Theory and Practice of Lex Non Scripta, Volume I. The University of Wisconsin Press, hlm. 20.

63 Ibid., hlm. 21.

64 Lihat Robert Cribb, 2010.

65 Lihat G.C. J.J. van den Bergh, Op.cit., hlm. 18, dan S. James Anaya, 1996, Indigenous Peoples in International Law, Oxford University Press, New York-Oxford, hlm. 11-12. 
hanya apabila ditentukan demikian oleh modern law. ${ }^{66}$

Penekanan pada aspek proses pembuatan menghasilkan istilah people's law/folk law/informal law/unofficial law/the living law yang dihadaphadapkan dengan istilah state law. Istilah-istilah peoples's law/folk law/informal law/unofficial law/ living law terbentuk lewat praktik sosial (social practices) sehari-hari sampai menjadi kebiasaan (custom) karena dianggap bernilai baik. ${ }^{67}$ Kebiasaan merupakan konsensus para anggota komunitas untuk meneruskan praktik-praktik sosial yang sudah berlangsung lama dan dianggap bermanfaat. ${ }^{68}$ Sedangkan state law, terutama legislasi, dibuat dengan proses mental yang melibatkan kelompok orang yang dianggap memiliki kewenangan, pengetahuan dan keahlian. ${ }^{69}$

Apabila menekankan aspek pelaksanaan atau pengadministrasian hukum maka ditemukan istilahistilah informal/unofficial law/the living law, untuk sistem hukum yang diadministrasi oleh asosiasiasosiasi sosial, dan formal/official law/state law, untuk yang diadministrasi oleh institusi negara.

Penekanan pada aspek substansi aturan mencermati seberapa jauh aturan yang dibuat dan berasal dari rakyat telah mengadopsi normanorma dari sistem-sistem hukum yang lain. Untuk yang sudah meresepsi norma-norma dari sistem hukum negara atau yang sudah dipengaruhi oleh pemikitan Hukum Barat, diberi nama dengan customary law. Beberapa ilmuwan sosial bahkan mengartikan istilah ini sebagai hukum penduduk jajahan hasil kreasi pemerintahan kolonial. Untuk konteks Indonesia, cara pandang ini digunakan oleh Daniel S. Lev untuk menyimpulkan hukum adat sebagai kreasi kaum kolonial sebagai metode untuk melanggengkan keterbelakangan golongan pribumi. $^{70}$ Salah satu alasan untuk menyimpulkannya sebagai kreasi kolonial karena customary law yang dijadikan acuan oleh pejabat pemerintahan dan lembaga pengadilan rezim kolonial adalah yang sudah dikompilasi atau bahkan dikodifikasi. Sementara kompilasi dan kodifikasi dilakukan dengan menerapkan pandangan Barat sehingga menghasilkan hukum adat sajian Barat. ${ }^{71}$ Customary law dibedakan dengan istilah indigenous law. Seperti sudah disebutkan sebelumnya, istilah ini dimaksudkan untuk menunjuk aturan-aturan di kalangan golongan pribumi negeri jajahan yang belum menerima pengaruh asing terutama hukumhukum agama. ${ }^{72}$ Aturan-aturan seperti ini disebut dengan indigenous law.

Untuk mendiskusikan lebih jauh relasi saling menerima elemen antara hukum yang dibuat dan berasal dari rakyat dengan sistem-sistem hukum lainnya, kajian-kajian sosial mengembangkan istilah atau konsep pluralisme hukum. Konsep ini bertujuan mengasah kepekaan untuk mengenali ragam sistem keteraturan (normative system) yang mengatur kehidupan sosial. ${ }^{73}$ Generasi kedua kajian pluralisme hukum ${ }^{74}$ menjelaskan bahwa berbagai sistem hukum yang co-exist melakukan relasi akomodatif dengan saling menerima elemen. Masing-masing sistem hukum tidak hidup

66 G.C. J.J. van den Bergh, Op.cit., hlm. 15-17; dan Brian Z. Tamanaha, 2001, A general Jurisprudence on Law and Society, Oxford University Press, Oxford, hlm. 24

67 Witteveen, Willem, "Law’s Begginings", dalam F.J.M. Feldbrugge, 2003, The Law's Begginings. Brill Academic Publishers, The Netherlands, hlm. 234.

68 Brian Z. Tamanaha, Op.cit., hlm. 5.

69 Roger Cotterell, 1984, The sociology of law an introduction, Second edition, Butterworths, London, Wignjosoebroto, Soetandyo, 1994, Dari Hukum Kolonila ke Hukum Nasional: suatu kajian tentang dinamika sosial-politik dalam perkembangan hukum selama satu setengah abad di Indonesia, 1840-1990, Rajagrafindo Persada, Jakarta, dan Brian Z. Tamanaha, 2001, A general Jurisprudence on Law and Society, Oxford University Press, Oxford.

70 Daniel S. Lev, 1990, Hukum dan Politik di Indonesia Kesinambungan dan Perubahan, LP3ES, Jakarta.

71 Francis G. Snyder, "Colonialism and Legal Form: The Creation of 'Customary Law' in Senegal”, Journal of Legal Pluralism\& Unofficial Law, Vol. 19, 1981, dan Francis G. Snyder, Ibid.

72 J.F. Holleman, (ed.), 1981, Van Vollenhoven on Indonesian Adat Law, Martinus Nijhoff, The Hague, hlm. 5, Chiba, Masaji, 1986, Asian Indigenous Law in Interaction with Received Law, Kegan Paul International, London dan New York, dan Ratno Lukito, 2008, Hukum Sakral dan Hukum Sekuler, Studi tentang Konflik dan Resolusi dalam Sistem Hukum Indonesia, Pustaka Alvabet, Jakarta.

73 Franz von Benda-Beckmann, "Who is Afraid of Legal Pluralism", Journal of Legal Pluralism and Official Law, Vol. 47, 2002, hlm. 37.

74 Mengenai pembagian generasi dalam perkembangan kajian Pluralisme Hukum dapat dilihat pada Woodman, 1998; dan Irianto, 2012: 157170 . 
dengan mengisolasi diri dengan cara memenuhi kebutuhannya sendiri. Menurut Hoekema yang terjadi adalah, "a process of adoption of elements of a dominant legal order, both national and international, and of the frames of meaning that constitute these orders, into the practices of alocal legal order and/or the other way round"..$^{75}$ Proses seperti itu dinamai interlegality.

Dalam perkembangannya, prosesinterlegality tersebut menghasilkan sebuah hasil (outcome) yang disebut sebagai hukum campuran (hybrid law). Istilah ini digunakan untuk menjelaskan normanorma yang tidak bisa lagi dikualifikasi sebagai hukum negara dan bukan hukum negara. ${ }^{76}$ Dari sisi sebab, norma campuran lahir karena penetrasi antar sistem norma hanya berujung pada tumpang tindih yang tidak sampai pada hubungan saling meniadakan atau saling menegasikan. ${ }^{77}$

Uraian di atas menjelaskan bahwa kajian sosial terus melakukan pengembangan untuk alasan agar bisa mengikuti sekaligus menjelaskan perubahan-perubahan pada sistem pengaturan nonnegara. Istilah-istilah baru dimunculkan bersamaan dengan perubahan penekanan aspek, termasuk untuk menyikapi munculnya gejala-gejala baru. Istilah hybrid law dimunculkan untuk menamai jenis informal law/unofficial law yang mengadopsi elemen-elemen hukum negara. Keluwesan untuk menghasilkan istilah-istilah baru tidak terlepas dari pengertian yang luas mengenai hukum oleh ilmu sosial. Griffiths (1986) misalnya, mengartikan hukum sebagai setiap aturan yang memiliki kemampuan untuk mengendalikan perilakuperilaku sosial. Aturan tidak hanya sebatas kaedah yang dihasilkan dari kesepakatan sosial tetapi juga mencakup kognisi. Dengan begitu, perilaku sosial yang terkendali atau tidak terkendali bukan hanya ditentukan oleh bekerjanya sistem aturan, misalnya dengan memaksa orang untuk patuh, tetapi dimulai dari persepsi dan kesadaran mengenai sistem aturan.

Karena itu, kajian sosial dengan cepat bisa memasukan aturan-aturan non negara yang baru kedalam cakupan kajiannya sepanjang memiliki fungsi kontrol sosial dan administrasinya dibawah otoritas institusi-institusi non negara. Sekedar menyebut contoh adalah penjelasan untuk selfregulating organizations berskala internasional yang dibentuk oleh pasar dengan tujuan mendorong sistem pengelolaan lingkungan dan sumber daya alam yang berkelanjutan. Metodenya adalah dengan menetapkan suatu standar pengelolaan dengan mengeluarkan sertifikasi pada produkproduk (pertanian, kehutanan) yang dihasilkan dari pengelolaan yang memenuhi standar tersebut. ${ }^{78}$ Sebagai contoh untuk organisasi semcama ini adalah Roundtable Sustainable Palm Oil (RSPO). ${ }^{79}$

Paparan di atas mengenai perbandingan pengertian hukum adat oleh Ilmu Hukum Adat Postivistik dan kajian sosial, menjelaskan dua situasi yang cukup berbeda. Pendekatan Ilmu Hukum Adat Positivistik, dalam menyikapi perubahanperubahan yang memicu kesenjangan antara konsep dan realitas, memilih untuk tidak meninjau ulang pengertian hukum adat. Kuatnya pengaruh pandangan yang mempolarisasi hukum adat dengan hukum negara, membuat pendekatan ini memilih untuk memahami perubahan-perubahan itu akan berujung pada bertahannya sebagai hukum adat

75 Andre J. Hoekema, "European Legal Encounters Between Minority and Majority Culture: Cases of Interlegality", Journal of Legal Pluralism\&Unofficial Law, Vol. 51, 2005, hlm. 11.

76 Sulistyowati Irianto, "Sejarah Pluralisme Hukum dan Konsekuensi Metodologisnya", dalam Tim HUMA, 2005, Pluralisme Hukum: Sebuah Pendekatan Interdisiplin. Perkumpulan HUMA, Jakarta.

77 Boaventura DeSausa Santos, "The Heterogeneous State and Legal Pluralism in Mozambique”, Law\&Society Review, Vol. 40, No. 1, 2006, dan Michaels Ralf, "Global Legal Pluralism”, 5 Annual Review of Law \& Social Science, 2009, hlm. 19.

78 Paiement, Phillip, 2017, Transnational sustainability laws, Cambridge University Press, Cambridge.

79 RSPO adalah forum nirlaba berskala internasional yang keanggotaanya bersifat multipihak meliputi kalangan industri minyak sawit, roduser minyak sawit, pengolah atau pedagang, penghasil barang-barang jadi, retailer, bank/investor, dan NGOs yang bergerak di isu lingkungan dan masyarakat. RSPO didirikan untuk mengembangkan dan meimplementasikan standar global mengenai pengelolaan kelapa sawit yang berkelanjutan (informasi diakses di https://www.rspo.org/about, 28 Oktober 2018). 
atau berubah menjadi hukum negara. Ini berbeda dengan pendekatan Ilmu Sosial yang menyikapinya dengan mengembangkan peristilahan termasuk memunculkan istilah baru bilaman menemui suatu gejala baru.

Perbedaan antara kedua pendekatan ini disebabkan juga oleh perbedaan pada orientasi atau tujuan. Pendekatan ilmu sosial berorientasi melukiskan gejala-gejala sosial bukan untuk keperluan menyelesaikan permasalahan (problem solving). Sementara itu, pendekatan Ilmu Hukum Adat Positivistik, seperti lazimnya pendekatan positivistik dalam kajian hukum, lebih berorientasi untuk menerapkan konsep dasar atau asas-asas hukum kedalam kasus-kasus konkret. Fokusnya bukan untuk menjelaskan kasus (realitas sosial), termasuk untuk melihat hal-hal partikular pada kasus, tetapi pada kerangka berpikir (konsep dasar, asas), dan kesimpulan sebagai hasil menerapkan kerangka berpikir pada kasus.

\section{Penutup}

Ilmu Hukum Adat Positif sejak mulai dirumuskan sudah menghadapi tantangan karena tujuan yang ditetapkannya sendiri. Tantangan pertama datang dari tujuan untuk menjadikan ilmu ini mentas dari Ilmu Hukum Positif dan tidak tergantung pada studi hukum adat empirik. Tantangan kedua datang dari tujuan agar ilmu ini dapat menyediakan pengetahuan mengenai hukum adat beserta nalar untuk memahaminya yang akan digunakan untuk keperluan penyelenggaraan pemerintahan. Kerja berat bukan hanya untuk urusan mewujudkan tujuan dengan harus menghadapi kedua tantangan tersebut, tetapi juga memastikan bahwa pencapaian kedua tujuan bisa dilakukan secara harmonis. Tujuan kedua berpotensi menyetir cara-cara untuk mencapai tujuan pertama sehingga hasil akhirnya bukanlah suatu disiplin ilmu tapi keterampilan.

Berkaitan dengan tujuan untuk tidak tergantung pada studi hukum adat empirik, ada sebuah isu yang sangat mendasar yaitu kemampuan Ilmu Hukum Adat Positif untuk menjelaskan objek secara akurat. Bila dirumuskan dengan cara lain, dengan mengklaim diri sebagai displin ilmu, bagaimana ilmu ini bisa menyajikan 'kebenaran' mengenai objeknya. Pertanyaan seperti ini muncul karena dalam sejarahnya Ilmu Hukum Adat Positif disusun dari etnografi hukum yang merupakan data-data empirik mengenai adat atau hukum adat. Dengan proposisi bahwa adat dan hukum adat adalah cara hidup atau praktik sosial dan karena itu terus bergerak mengikuti dinamika sosial, ilmu ini juga perlu mempertimbangkan gerak dan dinamika tersebut. Bila memasukannya dalam pertimbangan, minimal yang harus dilakukan adalah tetap meminjam atau menggunakan datadata dari pendekatan empirik untuk keperluan memahami atau meninjau konsep dasar atau asasasas hukum adat. Alasan bahwa Ilmu Hukum Adat Positif hanya mempelajari elemen tetap dari hukum adat yaitu konsep dasar dan asas, tidak bisa menjadi dalih untuk tidak perlu memberi perhatian pada fakta empirik (norma adat). Kecenderungan ini berpotensi menjadikan ilmu ini tidak akurat menjelaskan objeknya dan karena itu patut dicurigai bahwa ilmu ini lebih berfokus pada pencapaian tujuan yang kedua.

IlmuHukumAdatPositiftelahmengintroduksi dua bentuk konkret logika berpikir positivistik yaitu, Pertama, hubungan sebab akibat (cause and effect) antara konsep dasar, asas, dan kasus. Kedua, pembagian dikotomi antara yang hukum adat dan yang bukan hukum adat. Pembagian dikotomi ini adalah implikasi dari pemikiran bahwa sebagai sistem, elemen-lemen dalam hukum adat harus padu satu sama lain. Syarat untuk itu, tidak boleh ada anggapan bahwa hukum adat mengandung elemen dari sistem hukum lain. Sekalipun diakui sudah dipengaruhi atau menerima elemen-elemen dari sistem hukum lainnya, tetap disebut sebagai hukum adat. Konsep berpikir dikotomi ini, yang bermula dari konsep summa divisio dari Plato, berbeda dengan logika berpikir yang umumnya dipakai oleh orang Asia, yang melihat sesuatu selalu bersifat dinamik, tidak pernah sama pada tempat dan waktu yang berbeda. Sesuatu bisa sekaligus 
mengandung dua unsur yang berbeda dan keduanya bisa berkonsiliasi. ${ }^{80}$

Telaah tulisan ini mengenai Ilmu Hukum Adat Positif seluruhnya disandarkan pada data sekunder. Telaahan ini perlu dilanjutkan dengan mengandalkan data-data primer yang didapatkan dari penelitian lapangan. Data-data primer, tentu saja akan memiliki kekuatan yang lebih terutama karena menggambarkan kondisi kekinian. Telaahan data-data sekunder mengenai topik ini juga tidak kalah penting untuk diperbanyak. Sebagai suatu tulisan yang melakukan rintisan, masih terdapat bagian-bagian yang dijelaskan dengan tidak panjang lebar dalam tulisan ini sehingga perlu diteruskan.

\section{DAFTAR PUSTAKA}

\section{A. Buku}

Anaya, S. James, 1996, Indigenous Peoples in International Law, Oxford University Press, New York-Oxford.

Adi, Rianto, et al., 1998, Pola Penguasaan tanah masyarakat tradisional dan problema pendaftaran tanah, studi kasus di Sumatera Barat, Kalimantan Tengah, dan Nusa Tenggara Barat, Laporan Penelitian, Pusat Kajian Pembangunan Masyarakat Atma Jaya dan Badan Pertanahan Nasional, Jakarta.

Aspinall, Edward, et al., 2011, The state and illegality in Indonesia, KITLV Press, Leiden.

Ball, John, 1982, Indonesian Legal History 16021848, Oughtershaw Press, Sydney.

Barr, Christopher, et al., 2001, The Impacts of Decentralization on Forests and ForestDependent Communities in Malinau District, East Kalimantan, Center for International Forestry Research, Bogor.

Chiba, Masaji, 1986, Asian Indigenous Law in Interaction with Received Law, Kegan Paul International, London dan New York.

Collins, Hugh, 2001, Marxism and Law, Oxford University Press, New York.

Cotterell, Roger, 1984, The sociology of law an introduction, Second edition, Butterworths, London.
Darmodiharjo, Darji, et al., 2004 Pokok-pokok Filsafat Hukum: Apa dan Bagaimana Filsafat Hukum Indonesia, Gramedia Pustaka Utama, Jakarta.

Davidson, Jamie S., et al., 2007 The Revival of Tradition in Indonesian Politics: the deployment of adat from colonialism to indigenism, Routledge, London dan New York.

Dimyati, Khudzaifah, 2004, Teorisasi Hukum: studi tentang perkembangan pemikiran hukum di Indonesia 1945-1990, Muhammadyah University Press, Surakarta.

Djojodigoeno, M.M., 1958, Asas-asas Hukum Adat, Jajasan Badan Penerbit Gadjah Mada, Jogjakarta.

Holleman, J.F. (ed.), 1981, Van Vollenhoven on Indonesian Adat Law, Martinus Nijhoff, The Hague.

Koesnoe, Mohammad, 1979, Catatan-catatan terhadap Hukum Adat dewasa ini, Airlangga University Press, Surabaya.

Lev, Daniel S, 1990, Hukum dan Politik di Indonesia Kesinambungan dan Perubahan, LP3ES, Jakarta.

Lukito, Ratno, 2008, Hukum Sakral dan Hukum Sekuler, Studi tentang Konflik dan Resolusi dalam Sistem Hukum Indonesia, Pustaka Alvabet, Jakarta. 80 Patrick H. Glenn, "Asian thought and legal diversity”, dalam Gary F. Bell, 2017, Pluralism, transnationalism, and cultute in Asian law: a book
in honour of M.B. Hooker, ISEAS publishing, Singapore, hlm. 7. 
McCarthy, John F., 2006, The Fourth Circle A Political Ecology of Sumatra's Rainforest Frontier, Stanford University Press, Stanford, California.

Muhammad, Busar, 1981, Asas-asas hukum adat (suatu pengantar), Pradnya Paramita, Jakarta.

Paiement, Phillip, 2017, Transnational sustainability laws, Cambridge University Press, Cambridge.

Ralf, Michaels, "Global Legal Pluralism”, 5 Annual Review of Law \& Social Science, 2009

Slaats, Herman, et al., (ed.), 1993, Tiga Model Pendekatan Studi Hukum Adat: Suatu Laporan Penataran, Syahkuala University Press dan Pusat Studi Hukum Adat dan Islam Fakultas Hukum Universitas Syiah Kuala, Aceh.

Simarmata, Rikardo, 2006, Pengakuan Hukum terhadap Masyarakat Adat di Indonesia, Regional Initiative on Indigenous PeoplesUNDP, Jakarta.

Simarmata, Rikardo, et al., 2017, Masyarakat Hukum Adat sebagai Subyek Hukum, Kecakapan Hukum Masyarakat Hukum Adat dalam Lapangan Hukum Privat dan Publik, the Samdhana Institute, Yogyakarta.

Soedarso, R.H., "Studi hukum adat, dalam M. Syamsudin et al., 1998, Hukum Adat dan Modernisasi Hukum, Fakultas Hukum Universitas Islam Indonesia, Yogyakarta.

Sumaryono, E (2002) Etika Hukum Relevansi Teori Hukum Kodrat Thomas Aquinas. Jakarta: Penerbit Kanisius.

Soepomo, 2000, Bab-bab tentang Hukum Adat, Pradnya Paramita, Jakarta.

Sonius, H.W.J, “Introduction”, dalam J.F. Holleman, 1981, Van Vollenhoven on Indonesian Adat Law, Martinus Nijhoff, The Hague.

Tamanaha, Brian Z, 2001, A general Jurisprudence on Law and Society, Oxford University Press, Oxford.

T.M.C. Asser Instituut, 1992, Cornelis van Vollenhoven 1874-1933, The Hague.

Ubink, Janine, et al., (eds.), 2011, Customary
Justice: Perspective on Legal Empowerment, InternationalDevelopment Law Organization, Italy.

Van Vollenhoven, C, 1987, Penemuan Hukum Adat, Penerbit Djambatan, Jakarta.

Wignjosoebroto, Soetandyo, 1994, Dari Hukum Kolonila ke Hukum Nasional: suatu kajian tentang dinamika sosial-politik dalam perkembangan hukum selama satu setengah abad di Indonesia, 1840-1990, Rajagrafindo Persada, Jakarta.

\section{B. Artikel Jurnal} 2001, Hukum: Paradigma, Metode, dan Masalah, E lsam dan HUMA, Jakarta

Bakker, Laurens, "Illegality for The General Good? Vigilantism and Social Responsibility in Contemporary Indonesia", Critique of Anthropology, Vol. 35, No. 1.

Benda-Beckmann, Franz von, "Who is Afraid of Legal Pluralism", Journal of Legal Pluralism and Official Law, Vol. 47, 2002.

Cribb, Robert, "Legal Pluralism and Criminal Law in the Dutch Colonial Order", Indonesia, No. 90, Oktober 2010.

Djalins, Upik, "Re-examining subjek making in the Netherlands East Indies Legal Education: pedagogy, curriculum, and colonial state formation", Itinerario, Vol. XXXVII, No. 2, 2013.

Griffiths, John, "What is Legal Pluralism?”, Journal of Legal Pluralism\&Unofficial Law, Vol. 24, 1986.

Hoekema, Andre J., "European Legal Encounters Between Minority and Majority Culture: Cases of Interlegality", Journal of Legal Pluralism\&Unofficial Law, Vol. 51, 2005.

McCarthy, John F., "Between Adat and State: Institutional Arrangements on Sumatra's Forest Frontier", Human Ecology, Vol. 33, No. 1, February 2005.

Merry, Sally Engle, "Legal pluralism", Law and Society Review, Vol. 22, No. 5, 1988.

Santos, Boaventura DeSausa, "The Heterogeneous 
State and Legal Pluralism in Mozambique", Law\&Society Review, Vol. 40, No. 1, 2006.

Simarmata, Rikardo, "Menyoal Pendekatan Binar dalam Studi Adat, $L S D$, Vol. V, No. 2, JuneDecember, 2013.

Snyder, Francis G., "Colonialism and Legal Form: The Creation of 'Customary Law' in Senegal", Journal of Legal Pluralism\&Unofficial Law, Vol. 19, 1981.

Woodman, Gordon, "Ideological combat and social observation, recent debate about legal pluralism", Journal of Legal Pluralism and Official Law, Vol. 42, 1998.

\section{Makalah}

Simarmata, Rikardo, "Relevansi Menggagas Studi Kontemporer Hukum Adat", Makalah, Disampaikan pada Lokakarya Reorientasi Pengajaran dan Studi Hukum Adat, kerjasama Epistema Institute dan Fakultas Hukum Universitas Gadjah Mada, Yogyakarta, 7-8 Maret 2013.

\section{Antologi}

Bourchier, David, "Positivism and Romantism in Indonesian Legal Thought, dalam Timothy Lindsey (ed.), 1999, Indonesia Law and Society, The Federation Press, Australia.

Fitzpatrick, Daniel, "Land, custom, and the state in the post-Suharto Indonesia: a foreign lawyer's perspective, dalam Jamie S. Davidso, et al., 2007, The Revival of Tradition in Indonesian Politics: the deployment of adat from colonialism to indigenism. London and Routledge, New York.

Glenn, Patrick H., "Asian thought and legal diversity", dalam Gary F. Bell, 2017, Pluralism, transnationalism, and cultute in Asian law: a book in honour of M.B. Hooker, ISEAS publishing, Singapore.

Griffiths, John, "Recent Anthropology of Law in The Netherlands and its Historical Background", dalam Keebet von Benda-Beckmann dan Frons Strijbosch (eds.), 1986, Anthropology on law in the Netherlands: Essays in Legal Pluralism, Dordrecht-Holland/Cinnaminson, USA.

Hoekema, Andre J., "A New Beginning of Law Among Indigenous Peoples. Observation by Legal Anthropologist", dalam F.J.M., Feldbrugge, 2003, The law's begginings, Brill Academic Publishers, The Netherlands. Irianto, Sulistyowati, "Sejarah Pluralisme Hukum dan Konsekuensi Metodologisnya", dalam Tim HUMA, 2005, Pluralisme Hukum: Sebuah Pendekatan Interdisiplin. Perkumpulan HUMA, Jakarta. , "Pluralisme hukum dalam perspektif global", dalam Adrian W. Bedner, Sulistyowati Irianto, Jan Michiel Otto, dan Theresia Dyah Wirastri (eds.), 2012, Kajian sosio legal. Denpasar: Pustaka Larasan; Jakarta: Universitas Indonesia, Universitas Leiden, Universitas Groningen

Koesnoe, Mohammad, 1998, "Menuju kepada Penyusunan Teori Hukum Adat, dalam M. Syamsudin, et al., Hukum Adat dan Modernisasi Hukum, Fakultas Hukum Universitas Islam Indonesia, Yogyakarta.

Kurniawan, Joeni Arianto, "Gagasan Membangun (kembali) Ilmu Hukum Normatif: Konseptualisasi Mohammad Koesnoe tentang Hukum Adat sebagai Dasar Hukum Nasional Indonesia, dalam Joeni Arianto Kurniawan (ed.), 2013, Mohammad Koesnoe dalam pengembaraan gagasan hukum Indonesia, Epistema Institute\&HUMA, Jakarta.

Van den Bergh, G.C.J.J, "The Concept of Folk Law in Historical Context: A Brief Outline", dalam Alison Dundes Renteln, et al., 1994, Folk Law Essays in the Theory and Practice of Lex Non Scripta, Volume I. The University of Wisconsin Press.

Witteveen, Willem, "Law's Begginings", dalam F.J.M. Feldbrugge, 2003, The Law's Begginings. Brill Academic Publishers, The Netherlands. 